\title{
Largest baleen whale mass mortality during strong EI Niño event is likely related to harmful toxic algal bloom
}

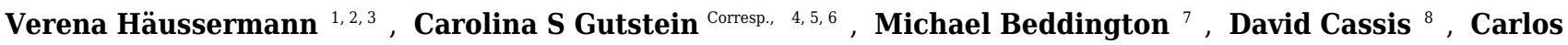 \\ Olavarria ${ }^{9,10}$, Andrew C Dale ${ }^{7}$, Ana M. Valenzuela-Toro ${ }^{6,11}$, MariaJose Perez-Alvarez ${ }^{\text {9, } 12}$, Hector H. Sepúlveda \\ ${ }^{13}$, Kaitlin M. McConnell ${ }^{3}$, Fanny E Horwitz ${ }^{14}$, Günter Försterra ${ }^{1,3,15}$ \\ 1 Facultad de Ciencias Naturales, Escuela de Ciencias del Mar, Pontificia Universidad Católica de Valparaíso, Valparaíso, Chile \\ 2 GeoBio-Center, Munich, Germany \\ 3 Huinay Scientific Field Station, Puerto Montt, Region de los Lagos, Chile \\ 4 Area de Patrimonio Natural, Consejo de Monumentos Nacionales, Santiago, Región Metropolitana, Chile \\ 5 Red Paleontológica U-Chile, Laboratorio de Ontogenia y Filogenia, Departamento de Biología, Facultad de Ciencias, Universidad de Chile, Santiago, \\ Región Metropolitana, Chile \\ 6 Department of Paleobiology, National Museum of Natural History, Smithsonian Institution, Washington, District of Columbia, United States \\ 7 Scottish Association for Marine Science, Oban, Scotland, UK \\ 8 Centro de Investigación e Innovación para el Cambio Climático, Universidad Santo Tómas, Santiago, Chile \\ 9 Centro de Investigación Eutropia, Santiago, Región Metropolitana, Chile \\ 10 Centro de Estudios Avanzados en Zonas Aridas (CEAZA), La Serena, Chile \\ 11 Ecology and Evolutionary Biology, University of California, Santa Cruz, Santa Cruz, California, United States \\ 12 Instituto de Ecología y Biodiversidad (IEB), Facultad de Ciencias, Universidad de Chile, Santiago, Chile \\ 13 Departamento de Geofísica, Universidad de Concepción, Concepción, Chile \\ 14 Facultad de Ciencias Naturales y Oceanográficas, Universidad de Concepción, Concepción, Chile \\ 15 Department of Zoology, Ludwig-Maximilians-University, Munich, Germany \\ Corresponding Author: Carolina S Gutstein \\ Email address: sgcarolina@gmail.com
}

While large mass mortality events (MMEs) are well known for toothed whales, they have been rare in baleen whales due to their less gregarious behaviour. Although in most cases the cause of mortality has not been conclusively identified, some baleen whale mortality events have been linked to bio-oceanographic conditions, such as harmful algal blooms (HABs).In southern Chile, HABs can be triggered by the ocean-atmosphere phenomenon El Niño. The frequency of the strongest El Niño events is increasing due to climate change. In March 2015, by far the largest reported mass mortality of baleen whales took place in a gulf in southern Chile. Here we show that the synchronous death of at least 343, primarily sei, whales can be attributed to HABs during a building El Niño. Although considered an oceanic species, the sei whales died while feeding near to shore in previously unknown large aggregations. This provides evidence of new feeding grounds for the species. The combination of older and newer remains of whales in the same area indicate that MMEs have occurred more than once in recent years.Large HABs and reports of marine mammal MMEs along the north-east Pacific coast may indicate similar processes in both hemispheres. Increasing MMEs through HABs may become a serious concern in the 
conservation of endangered whale species. 
3 Verena Häussermann ${ }^{1,2,3}$, Carolina S Gutstein ${ }^{4,5,6}$, Michael Beddington 7 , David Cassis ${ }^{8}$, Carlos Olavarria ${ }^{9,10}$,

4 Andrew C. Dale', Ana M. Valenzuela-Toro, ${ }^{611}$, Maria Jose Perez-Alvarez, ${ }^{92}$, Hector H. Sepúlveda' ${ }^{13}$, Kaitlin M.

$5 \quad$ McConnell ${ }^{3}$, Fanny E. Horwitz ${ }^{14}$, Günter Försterra' ${ }^{1,3,15}$

7 'Facultad de Ciencias Naturales, Escuela de Ciencias del Mar, Pontificia Universidad Católica de Valparaíso,

8 Valparaíso, Chile

$9 \quad{ }^{2}$ GeoBio-Center, Munich, Germany

10 ${ }^{3}$ Huinay Scientific Field Station, Puerto Montt, Region de los Lagos, Chile

$11{ }^{4}$ Area de Patrimonio Natural, Consejo de Monumentos Nacionales, Santiago, Región Metropolitana, Chile

12 sRed Paleontológica U-Chile, Laboratorio de Ontogenia y Filogenia, Departamento de Biología, Facultad de

13 Ciencias, Universidad de Chile, Santiago, Región Metropolitana, Chile

14 'Department of Paleobiology, National Museum of Natural History, Smithsonian Institution, Washington,

15 District of Columbia, United States

$16 \quad{ }^{7}$ Scottish Association for Marine Science, Oban, Scotland, UK

$17{ }^{8}$ Centro de Investigación e Innovación para el Cambio Climático, Universidad Santo Tómas, Santiago, Chile

$18{ }^{9}$ Centro de Investigación Eutropia, Santiago, Región Metropolitana, Chile

$19{ }^{10}$ Centro de Estudios Avanzados en Zonas Aridas (CEAZA), La Serena, Chile

20 "Ecology and Evolutionary Biology, University of California, Santa Cruz, Santa Cruz, California, United

21 States 
22 12Instituto de Ecología y Biodiversidad (IEB), Facultad de Ciencias, Universidad de Chile, Santiago, Chile

$23 \quad{ }^{13}$ Departamento de Geofísica, Universidad de Concepción, Concepción, Chile

$24 \quad{ }^{14}$ Facultad de Ciencias Naturales y Oceanográficas, Universidad de Concepción, Concepción, Chile

$25 \quad{ }^{15}$ Department of Zoology, Ludwig-Maximilians-University, Munich, Germany

26 Corresponding Author: Carolina S. Gutstein, Vicuña Mackenna 84, Providencia, Región Metropolitana, Chile, e27 mail address: sgcarolina@gmail.com 


\section{ABSTRACT}

29 While large mass mortality events (MMEs) are well known for toothed whales, they have

30 been rare in baleen whales due to their less gregarious behaviour. Although in most cases the

31 cause of mortality has not been conclusively identified, some baleen whale mortality events have

32 been linked to bio-oceanographic conditions, such as harmful algal blooms (HABs). In southern

33 Chile, HABs can be triggered by the ocean-atmosphere phenomenon El Niño. The frequency of

34 the strongest El Niño events is increasing due to climate change. In March 2015, by far the

35 largest reported mass mortality of baleen whales took place in a gulf in southern Chile. Here we

36 show that the synchronous death of at least 343, primarily sei, whales can be attributed to HABs

37 during a building El Niño. Although considered an oceanic species, the sei whales died while

38 feeding near to shore in previously unknown large aggregations. This provides evidence of new

39 feeding grounds for the species. The combination of older and newer remains of whales in the

40 same area indicate that MMEs have occurred more than once in recent years. Large HABs and

41 reports of marine mammal MMEs along the north-east Pacific coast may indicate similar

42 processes in both hemispheres. Increasing MMEs through HABs may become a serious concern

43 in the conservation of endangered whale species. 


\section{INTRODUCTION}

45 Although most populations of whales have been fully protected from industrial hunting for half a

46 century, some were reduced to such low levels that recovery is still very slow (Baker \&

47 Clapham, 2004). Today, whales face additional threats, such as ship strikes, entanglement and

48 by-catch, underwater noise, pollution and habitat loss (Clapham et al., 1999). Moreover, since

49 ocean conditions directly influence quality and availability of the prey species of baleen whales,

50 the effects of climate change will become a concern (Simmonds \& Isaac, 2007). 
Mass mortality events (MME) of marine mammals generally involve social species such

52 as dolphins or sea lions, but are rare in baleen whales due to their less gregarious behaviour

53 (Perrin et al., 2009a). When MMEs have occurred in baleen whales they have often extended over several months and large areas, involving mostly coastal whales (Table 1). In the Northeast

55 Pacific, seven to eight times more gray whales (Eschrichtius robustus) washed ashore during the

years 1999 and 2000 than is usual in such a time span. Of these, 106 died within a three-month period in Mexico (Gulland et al., 2005). In the course of 2012, 116 southern right whales (Eubalaena australis), mostly calves, washed ashore at their breeding ground in Valdés Peninsula, Argentina (Anonymous, 2015). During 2009, 46 humpback whales (Megaptera novaeangliae) stranded in Australia (Coughran et al., 2013) and 96 in Brazil during 2010, most of them calves and juveniles (Rowntree et al., 2013). Less frequent and much smaller in magnitude are sudden and locally restricted baleen whale mortalities. The largest of those involved 14 humpback whales which died around Cape Cod during five weeks in November 1987 (Geraci et al., 1989) (Table 1). The causes of most MMEs have not been conclusively identified (e.g. Anonymous, 2015; Coughran et al., 2013; Gulland et al., 2005); however, paralytic shellfish poisoning during harmful algal blooms (HABs) has been argued as one of the main likely causes (and this is also the case for other marine vertebrate mass mortalities; Geraci et al., 1989; Durbin et al., 2002; Doucette et al., 2006; Rowntree et al., 2013; Cook et al., 2015; D'Agostino et al., 2015; Wilson et al., 2015; Lefebre et al., 2016). 
71 Alexandrium with production of Paralytic Shellfish Toxins (PST). HABs have been of concern to

72 fishermen and Patagonian communities since at least 1972, when the first mass intoxication was

73 recorded (Suárez and Guzmán, 2005). Since then, the geographic region in which blooms have

74 been detected has increased to over $1000 \mathrm{~km}$ north-south extent (Molinet et al. 2003). HABs

75 have also become more frequent, becoming annual events with blooms normally occurring in

76 large areas during the summer and fall (Guzmán et al., 2002). Due to the danger posed by these

77 toxins, the Chilean government funds a monitoring program with over 200 sampling stations

78 throughout the southern part of Chile, where phytoplankton and shellfish samples are obtained

79 and later analysed for the presence of microalgae and their toxins (paralytic shellfish toxin PST,

80 amnesic shellfish toxin AST, diarrheic shellfish toxin DST) (Suárez and Guzmán, 2005).

81 Unfortunately, mainly due to the difficulty accessing many sites, these biotoxin data are only

82 available for a limited coastal area of southern Chile. 
84 extensive fjord regions, with a north-south extent of approximately $1,500 \mathrm{~km}\left(42^{\circ} \mathrm{S}\right.$ to $\left.55^{\circ} \mathrm{S}\right)$, covering an area of over $240,000 \mathrm{~km}^{2}$ and with a coastline of more than $80,000 \mathrm{~km}$, made up of numerous fjords, channels and islands. At the same time this is one of the least scientifically understood marine regions of the world (Försterra, 2009; Försterra et al., in press). Precipitation can locally exceed $6,000 \mathrm{~mm}$ per year and the tidal range can exceed $7 \mathrm{~m}$. The prevailing strong westerly winds make its exposed shores amongst the most wave-impacted in the world (Försterra, 2009). These factors are responsible for the inaccessibility of a large part of this region. Chilean Patagonia is subdivided into the North, Central and South Patagonian Zone (for a summary of biogeography of the region see Häussermann and Försterra, 2005 and Försterra et al., in press). The remote area around Golfo de Penas and Taitao Peninsula (Fig. 1) is situated in 94 the Central Patagonian Zone between $47^{\circ} \mathrm{S}$ and $48^{\circ} \mathrm{S}$. Except for two Chilean Navy lighthouses 95 at Cabo Raper and San Pedro, the closest human settlements are more than $200 \mathrm{~km}$ away (Tortel, 96 Puerto Aysén and Puerto Edén). 
98 (onshore) flow which diverges at the coast to form the northward Humboldt Current and the southward Cape Horn Current (Thiel et al., 2007). The fjordic nature of the coastline produces significant local complexity, with many inlets and dispersed freshwater sources. High productiv-

101 ity in these coastal waters (Fig. 2) is driven by the availability of both terrestrial nutrients, carried 102 by large rivers originating at the Northern and Southern Patagonian Icefields, and marine nutri103 ents (González et al., 2010; Torres et al., 2014). While this region experiences coastal winds that 104 favor net coastal downwelling, intermittent and/or localized upwelling, in particular in summer 105 and north of Taitao Peninsula $\left(47^{\circ} \mathrm{S}\right)$, is expected to enhance the supply of marine nutrients to 106 coastal waters, and the relative balance between upwelling and downwelling varies from year to 107 year.

108 During a vessel-based scuba diving expedition, "Huinay Fiordos 24" (HF24), focused on 109 benthic fauna between Golfo Tres Montes (northern Golfo de Penas, 46³0'W) and Puerto Eden $110\left(49^{\circ} \mathrm{S}\right)$, dead baleen whales and skeletal remains were discovered south of Golfo de Penas and at 111 Golfo Tres Montes. Here we describe by far the largest ever recorded MME of baleen whales at 112 one time and place. Our analyses focus on the location and cause of the mortality.

\section{$114 \quad$ Field surveys}


116 inventory the benthic fauna of the area between Golfo Tres Montes (northern Golfo de Penas, $\left.46^{\circ} 30^{\prime} \mathrm{W}\right)$ and Puerto Edén $\left(49^{\circ} \mathrm{S}\right)$. By chance, VH and her team discovered recently dead baleen whales and skeletal remains in and close to the entrance of the $14 \mathrm{~km}$ long Estero Slight and in the Canal Castillo situated $235 \mathrm{~km}$ to the south (Figs. 1, 3, Table 2). Georeferences and photographs of different views were taken, whales measured, and species and sex identified whenever possible. Between May 25 and 31, the Chilean Fisheries Service (SERNAPESCA), with the support of the Chilean Navy (Armada) and the Criminal Investigation Department of the Civil Police (PDI), organized a vessel-based trip to the location of the dead whales in Estero Slight to investigate possible anthropogenic reasons behind the mortality. During this trip, genetic samples for species identification were taken, one ear bone was extracted and stomach and intestine contents of two whales were tested for presence of PST and AST (Fiscalía de Aysén, 2015). During a subsequent aerial survey on-board a high wing airplane Cessna 206, between June 23 and 27, 2015, CSG, VH and FH surveyed the coasts along the shores of Golfo de Penas. This aerial survey covered the coastal area between the Jungfrauen Islands $\left(48^{\circ} \mathrm{S}\right)$ and Seno Newman (46 $39^{\prime}$ S) from altitudes between $100 \mathrm{~m}$ and $850 \mathrm{~m}$ and at speeds between $100 \mathrm{~km} / \mathrm{h}$ and $200 \mathrm{~km} / \mathrm{h}$ (Figs. 1, 4, Table 2). Due to limited flying time (unstable weather conditions and the inability to refuel in the area) data collection was focused on counting whale carcasses, recording GPS positions and taking photographs. A GoPro camera filmed continuously until reaching Seno Newman. The researchers on the flight counted carcasses and marked their coordinates while an audio recorder captured the carcass number, position, orientation, photo number, photographer and geomorphology of the beach. Whale counts were repeated in all areas except Seno Newman due to adverse weather conditions. Since there are no landing opportunities in this remote and unpopulated area it was not possible to take samples or close-up photos, or to search for additional whale bones. 
140 In addition to the whale carcasses and skeletons from the two surveys, some whale 141 carcasses and skulls were reported between February and June 2015 by boat crews navigating 142 the west coast of Taitao Peninsula and the coast between $49^{\circ} 15^{\prime}$ and $51^{\circ} \mathrm{S}$ (Table 2 ). Between 143 January 23 and March 1, 2016 (Expedition Huinay Fiordos 27) and between April 27 and May 144 30, 2016 (Expedition Huinay Fiordos 29), two additional vessel-based expeditions were carried 145 out, each to Seno Escondido, Seno Newman and Estero Slight, with the aim of searching for new 146 carcasses, taking samples for genetic and red tide analyses, and performing oceanographic 147 transects. Data from those surveys are included here, but most of the analyses of the samples will 148 be published in a separate paper.

149 Samples of marine invertebrates were collected under permit of Subsecretaria de Pesca y 150 Acuicultura (R.EX. 1295 del 27.04.2016). Samples of cetacean carcasses were authorized by 151 SERNAPESCA, Region de Aysen (Acta Numbers 2016-11-10 and 12).

\section{Satellite image}


A high resolution satellite image was taken of Seno Newman on August 13, 2015 using

154 the Pleiades-1 Satellite. The 16-Bit ortho-rectified GeoTIFF Multispectral (R-G-B-NIR) and

155 Panchromatic files have been analyzed to count whale carcasses and determine their geographic

156 positions (Fig. 5). The whales identified in the satellite image were compared to the photos and

157 GPS locations obtained during the overflight, and cross matched with reference to nearby 158 geomorphological features.

\section{Taxonomic analysis}

Whales were identified in situ during the vessel-based expedition based on morphological

characteristics. The species identification of the specimens from which tissue was sampled

during the SERNAPESCA expedition to Estero Slight was confirmed genetically by MJP

(Fiscalía de Aysen, 2015). A 675 bp fragment of mitochondrial DNA control region was

amplified using the primers using the primers M13 Dlp1.5 5'-

TGTAAAACGACAGCCAGTTCACCCAAAGCTGRARTTCTA-3’’ and 8G 5

166 'GGAGTACTATGTCCTGTAACCA (Dalebout et al. 2005) and sequenced in both directions.

167 Amplification reactions were performed in a total volume of $25 \mu 1$ with $5 \mu 1$ PCR buffer $10 \mathrm{X}, 2$

$168 \mu \mathrm{MgCl} 250 \mathrm{mM}, 1 \mu \mathrm{l}$ of each primer, $2 \mu \mathrm{dNTP} 200 \mathrm{mM}$ and $0.3 \mu 1$ Taq DNA polymerase

169 (Invitrogen Life Technologies) and 50 ng DNA. The PCR temperature profile was as follows: a

170 preliminary denaturing period of $2 \mathrm{~min}$ at $94{ }^{\circ} \mathrm{C}$ followed by 30 cycles of denaturation for $30 \mathrm{~s}$ at

$17194{ }^{\circ} \mathrm{C}$, primer annealing for $40 \mathrm{~s}$ at $56{ }^{\circ} \mathrm{C}$ and polymerase extension for $40 \mathrm{~s}$ at $72{ }^{\circ} \mathrm{C}$. A final

172 extension period for $10 \mathrm{~min}$ at $72{ }^{\circ} \mathrm{C}$ was included. 


\section{Taphonomy}

Analysis was carried out, following biostratinomic criteria, on different subsets of the whale remains recorded during the overflight and the vessel-based surveys. Characterization of the depositional state of the carcasses was based on a post hoc analysis of the assemblage, exclusively through photographs, classifying the carcasses into three taphonomic classes according to previous studies of biostratinomic processes in marine mammals (Pyenson et al., 2014, Liebig et al., 2003, 2007, Schäfer, 1972). The aspects considered were: anatomic position of the carcasses (ventral, dorsal or lateral side up; $n=201$ ), deposition site (rocky or sandy, $\mathrm{n}=295$ ), and the disarticulation and degree of decay of the carcasses. These final two aspects were sorted into classes to estimate the sequence of disarticulation/decay addressing two aspects: time since death $(\mathrm{n}=245)$ and drift time/distance of the carcass (as a proxy to estimate the relative location of death, $\mathrm{n}=151)$.

To assess the time since death, three categories were defined, reflecting a straightforward order from the least decomposed to the most disarticulated carcass/skeleton. "Class 1" refers to carcasses in the lowest to relatively medium state of decomposition for these assemblages.

Included in this category are complete carcasses with skin, complete carcasses without skin, and complete carcasses with partially exposed bones (see Fig. 6A). "Class 2" includes carcasses in a relatively greater state of decomposition but still maintaining their longitudinal axis, although some bones may be scattered (see Fig. 6B). Finally, "Class 3" refers to isolated skeletal remains with no soft tissue, such as skulls, dentaries or postcranial remains (see Fig. 6C). Thus, the sequence of "time since death" should reflect ranges from less than 3 months (Class 1), several months, but probably less than 6 months (Class 2), to a year or more (Class 3). 
The analysis of the location of death, namely whether the carcasses are paraautochthonous or allochthonous, was addressed by evaluation of the time that the carcasses had remained floating in the water column and at the surface (see Schäfer, 1972). For this, we defined two classes, depending of the presence or absence of the skull, as a proxy for the time floating and the potential distance between the site of mortality and the observed site of deposition (Fig. 7) (Toots, 1965; Voorhies, 1969; Behrensmeyer 1973; Holz and Simoes, 2002; Liebig, 2003). Thus, "Class A" includes carcasses that preserve the skull and "Class B" includes those without a skull. For this analysis we excluded skeletons which were considered older than a year (minimum age, based on field observations of AVT from 2016 expedition to the site of the mortality). A geomorphological analysis was made using photographs and Google Earth (Terrametrics, 2015). We classified the type of depositional locality (i.e. sand/pebble dominated beach or rocky outcrop) (Table 2) in order to assess the relationship between these aspects and the taphonomic categories mentioned above; for instance, whether carcasses that had been transported further and disarticulated (allochthonous) were more prevalent at high energy sites (i.e. rocky outcrops) and articulated (para-autochthonous) carcasses more prevalent in low energy environments (i.e. sandy beaches). 
211 To compare the density of the death assemblages at Golfo de Penas with known extinct

212 and extant death assemblages recorded in the literature, we measured linear dimensions of the

213 geomorphological units (i.e. length and width of the beach), through the measure tool in Google

214 Earth, using the highest resolution satellite images available, at sites where assemblages were

215 found. In this manner, the geographic areas corresponding to the death assemblages were

216 calculated and the density determined by dividing the number of specimens in each assemblage

217 by its area.

Analysis of the petrotympanic complex (ear bone)

219 CSG studied the bones of the middle and inner ear of one whale, collected during the

220 SERNAPESCA expedition. A volumetric computed tomography in the Morita tomograph (box of

$22160 \mathrm{~mm}, 500$ cuts) was carried out. The images were visualized with Osirix Dicom viewer v 5.6

222 32-bit in search for fractures or micro-fractures, which would appear as black gaps in the bony

223 tissue. 
Bivalve tissue was sampled in Estero Slight on April 22 and on May 25, 2015 (2 samples

March 1, and April 27 and May 30, 2016 (22 samples in total). The stomach content and intestine content of two whales from Estero Slight were sampled on May 25, 2015. On February, 2016, one sample of duodenum content was obtained from a freshly dead whale observed in Estero Slight. At the same period, one sample of surface-swimming Munida spp. was collected at $46^{\circ} 29.730^{\prime} \mathrm{S}, 74^{\circ} 55.722^{\prime} \mathrm{W}$. All samples were analyzed in situ for presence of PST using the protocol already described for the shellfish tissue and stomach content samples. Samples from 2015 were analyzed by DC, while the samples from 2016 were analysed by KMC. The tissue was homogenized using a blender and mixed in a 1:1 ratio with a field extraction fluid composed of 2.5 parts of rubbing alcohol $(70 \%)$ to one part white vinegar. The mixture was then homogenized manually and filtered through a paper filter (paper filter \#4). The extract obtained after filtration was then used to detect the presence of toxins through rapid field test kits from Scotia Rapid Testing for PST and AST. For this, $100 \mu$ of the extract was placed in a test tube containing running buffer, mixed and then $100 \mu \mathrm{l}$ of this mixture was placed in a lateral flow ELISA (enzyme-linked immunosorbent assay) test strip with antibodies specific for PST (saxitoxin and its derivative toxins) and AST (domoic acid). These tests were left to develop for 1 hour before the results were read. 
244 Seno Escondido between January 23 and March 1, and April 27 and May 30, 2016, using a 20

$245 \mu \mathrm{m}$ mesh size plankton net in a vertical tow from $15 \mathrm{~m}$ depth. The phytoplankton present in these samples was concentrated using the net, and a $100 \mu \mathrm{l}$ subsample was placed in a tube with $0.1 \mathrm{M}$ acetic acid and mixed. $100 \mu \mathrm{l}$ of this mixture were then added to a test tube containing running buffer and an aliquot of this mixture of the same volume was placed in a ELISA test strip for PST and left to develop for one hour before results were read.

These qualitative PST test strips are extremely sensitive due to the local toxin profile, which is high in GTX2/3, resulting in detection limits below $32 \mu \mathrm{g} \mathrm{STX} \mathrm{Eq/100} \mathrm{g}$ of tissue. The detection limit for the AST tests was reduced to 2 ppm of domoic acid by modifying the standard sample preparation protocol by eliminating the dilution of the sample before mixing it with the buffer. communication, 2015), in which mytilid samples are analyzed at several stations throughout

\section{Drift model}


263 Floating objects are directly affected by surface currents, wind and waves. Wind both drives the

264 Ekman drift of surface water (Ardhuin et al., 2009) and exerts a direct drag on the emerged

265 surface of an object (Breivik et al., 2012). Stokes drift, the net forward transport due to non-

266 closed particle trajectories resulting from passing waves, also contributes to the transport of

267 floating objects. The drift of whale carcasses was simulated by parametrising the contribution of

268 these components, based on objects of a similar size from search and rescue models (Breivik et

269 al., 2012; Peltier et al., 2012). Due to the large uncertainty in carcass drift characteristics,

270 parameters were varied stochastically within a wide range of possible values.

Use was made of existing current and wave products, the HYCOM daily $1 / 12$ simulation

272 (Wallcraft et al., 2009), and waves from ECMWF ERA-Interim reanalysis (Dee et al., 2011).

273 Winds were taken from a custom downscaling of NCEP NFL boundary conditions using the

274 WRF model (Skamarock et al., 2008) to a sub-4 km grid size. Drift scenarios were run by stepping forward in time from hypothetical sites and times of mortality. All of these sites were in shallow water, since carcasses resulting from mortality in deep water have a tendency to sink and not resurface (Smith et al., 2015). A horizontal diffusion coefficient of $10 \mathrm{~m}^{2} \mathrm{~s}^{-1}$ was included in drift tracks to represent unresolved physical processes. While the resolution of the current and wave datasets is inadequate to represent detailed coastline or seabed geometry, or the interior of the fjords, the drift model does clarify the expected distribution and spread of carcasses from 281 localized sources. 


\section{Large scale wind stress}

The large-scale tendency toward upwelling or downwelling provides a key driver of coastal ecosystems. This was assessed using ECMWF ERA-Interim reanalysis data (Dee et al., 2011). It is the alongshore component of wind stress that drives Ekman transport normal to the coast and consequent upwelling or downwelling. Since upwelling and downwelling are cumulative processes, a time-integrated wind stress was calculated (e.g. Pierce et al., 2006) from a base time of the vernal equinox (September 21). Stress was estimated from reanalysis winds at 10 m elevation according to Large and Pond (1981). The large scale change in coastal orientation was taken into account in extracting the alongshore wind component, although localized inlets, bays (including the Golfo de Penas) and islands were not considered.

\section{RESULTS}

\section{Field surveys and toxicity tests}

Of the total of dead whales observed in all expeditions and reports in 2015 (367), 35 recently dead whales and 12 skeletal remains were discovered during the HF24 expedition: 31 carcasses and 12 skeletal remains were found in and close to the entrance of the $14 \mathrm{~km}$ long Estero Slight and four carcasses in Canal Castillo, situated $235 \mathrm{~km}$ to the south, as well as many whale bones on different beaches (Fig. 3, Table 2). Three-hundred and five carcasses were mapped during the overflight between the Jungfrauen Islands $\left(\sim 48^{\circ} \mathrm{S}\right)$ and Seno Newman (46 $\left.36^{\circ} \mathrm{S}\right)$. In addition to this total of 284 whale carcasses and 21 skeletons from the two surveys, 51 whale carcasses and 11 whale skulls were reported between February and June 2015 by boat crews navigating the west coast of Taitao Peninsula and the coast between $49^{\circ} 15^{\prime}$ and $51^{\circ} \mathrm{S}$ (Table 2 , Fig. 4). 

and/or sea lions) were seen, but due the flying altitude, speed and weather conditions, the photo quality and resolution did not allow their conclusive identification as actual carcasses. In Estero Slight, one dead pinniped was found on the shore from the vessel. During the SERNAPESCA expedition one Otariidae skull was found and photographed in the same channel but the correspondence of the carcass and the skull could not be established.

The 28 whale carcasses that could be identified unambiguously to species level were all sei whales (Balaenoptera borealis); 15 of these identifications were confirmed genetically. Seven specimens could be identified as males and ten as females. One hundred and twenty-nine carcasses were identified as baleen whales of the Balaenopteridae family or rorquals. The 30 whales examined in detail in Estero Slight during the vessel-based expedition were between $6 \mathrm{~m}$ and $15 \mathrm{~m}$ long, hence included both juvenile and fully grown specimens. anatomic structures of the ear bone were in good condition showing no damage; the stapes were articulated in place, and the bony tissue showed no fractures (Fig. 8). The analysis of locally collected mytilids in April and May 2015 and of the stomach and intestine content of two whales in May 2015 showed presence of PST and AST. 

expeditions to Golfo Tres Montes; five further were reported by boat crews navigating the southern part of Chilean Patagonia. None of the examined whales showed any evidence of disease or traumatic damage. Thirty-six rapid tests on PST were run using mussels (12 tests),

324 Munida (2 tests), and phytoplankton (22 tests) in Seno Escondido, Seno Newman and Estero 325 Slight. Most of the samples collected during the 2016 expeditions proved to be negative for the 326 presence of PST, nevertheless, both expeditions detected the presence of PSP in the phytoplankton collected at the entrance of Seno Newman. A sample collected at the head of Seno

328 Newman was negative for PST, indicating that the toxic phytoplankton was preferentially located 329 at the mouth of this inlet and nearby areas of the Canal Chaicayán.

\section{Biostratinomic analysis}

Of the 367 dead whales observed in 2015, 305 carcasses were mapped between Seno

332 Newman $\left(46^{\circ} 39^{\prime} \mathrm{S}\right)$ and Jungfrauen Islands $\left(\sim 48^{\circ} \mathrm{S}\right)$. Those carcasses could be grouped into five assemblages (Figs. 1, 9, Table 2), defined as a group of carcasses in close proximity. The assemblages were called Golfo de Penas, Jungfrauen Islands, Seno Escondido, Seno Newman and Estero Slight. 
$336 \quad$ Some carcasses were floating (11), but most (284) were deposited ashore (Figs. 3 to 5).

337 The greater proportion of carcasses were deposited in a lateral position and to a lesser extent in

338 the ventral-up position reflecting the hydrodynamics of the body in the sea as determined by the

339 inflation of the abdominal region and mainly of their tongues, as observed in a recently dead

340 individual and in some decayed carcasses at Golfo de Penas (Fig. 10). In general, they were

341 tide-oriented (parallel to the coast line) and all of the classified carcasses from the overflight

342 were lying on their back or side (ventral up, 44.3\%; lateral up, 55.7\%) (Table 3, Fig. 11C), while

343 only one specimen (from HF24) was found in a dorsal up position (data not included in analysis

344 due to different time of observation).

345 With respect to the classification of "time since death", $68.8 \%$ of the carcasses were

346 classified in class 1 (less than 3 months), 24.9\% in class 2 (less than 6 months) and 6.3\% in class

3473 (more than a year) (Fig. 11A-B, Table 4). With respect to "time at sea", 147 (87\%) of the

348 carcasses were classified in class A (short time/distance of drift), while only four (13\%) were

349 identified as class B (long time/distance of drift) (Fig. 11 C, Table 4). There was no pattern

350 relating the geomorphological unit (sandy: $34 \%$, pebble: $27 \%$, rocky beach: $34 \%$ ) to the

351 taphonomic classes. 
352 The carcasses found in April in Estero Slight were classified in stage 2 of Geraci and

353 Lounsbury (2005) indicating a few days to weeks since death; this would be classified as class 1

354 in the taphonomic classes of the present study.

355 The density of whale carcasses was in average $1050 / \mathrm{km}^{2}$, considering all assemblages

356 recognized (Table 5). 


\section{Carcass drift and potential source locations}

The distribution of beached carcasses was simulated from four illustrative source locations (Fig. 12A-D). In each case, calculations tracked 13000 hypothetical carcasses, reflecting source times spanning a 2-month period from mid-February to mid-April 2015 and a range of drift model parameters. The spread of stranding locations therefore represents variability of the current, wind and wave environment during this period as well as the uncertainty in model parameters and a diffusive component to the drift tracks. While each of the illustrated source locations leads to strandings distributed over several hundred kilometres of coastline, there are important differences in these distributions. A simulated source in Golfo Tres Montes (northern Golfo de Penas) leads to strandings throughout the Golfo de Penas (Fig. 12A), including in the Golfo Tres Montes itself. No other source location (Fig. 12B-D) leads to strandings in Golfo Tres Montes due to the direction of prevailing currents and the sheltering effect of Peninsula Taitao. Similarly, only a source to the north of Peninsula Taitao leads to strandings in that region (Fig. 12B). Carcasses originating in the Golfo de Penas have a tendency to be transported to the south by prevailing currents (Fig. 12A, C, D).

\section{Inter-annual variation in upwelling or downwelling}


373 Comparison between the cumulative alongshore wind stress for the year in question and 374 the previous 20 years (Fig. 13) reveals that the months immediately prior to the mortality event 375 were anomalous. North of the study area, at $45^{\circ} \mathrm{S}$, there was an anomalously strong tendency 376 toward upwelling (an upward trend in Fig. 13), making this one of the most upwelled years of 377 the period. At the latitude of Golfo de Penas and further south there was a net tendency to 378 downwelling (a downward trend in Fig. 13), but punctuated by upwelling events, making this 379 one of the least downwelled years of the period.

\section{DISCUSSION}

381 Possible causes of death (Table 6) need to be analysed for a mechanism that is capable of 382 synchronous killing of hundreds of whales, apparently all or most of the same species (with few 383 exceptions, i.e. one confirmed pinniped). Baleen whales, in contrast to odontocetes, are less social and do not use echolocation to navigate (Perrin et al., 2009b). The latter characteristics are key aspects used to explain mass mortalities in odontocetes. 
387 contagious unknown virus or infection, noise-related mechanisms at sea, and intoxication by

388 biotoxins (domic acid, saxitocin, etc; Geraci et al., 1989; Fire et al., 2010; Lefebvre et al., 2016;

389 Pyenson et al. 2014, Table 6). In this assemblage the individuals could not be tested for viruses

390 or bacteria, due to their advanced state of decomposition. There was no evidence of pathological

391 modifications that could be attributed to such a cause, however, it is not possible to completely

392 discard this hypothesis. 
393 The only potentially lethal noise-related mechanism for a baleen whale are very intense noises

394 associated with blasting in close proximity (Ketten 1992). This could injure the animal and cause

395 haemorrhage or provoke panic, disorientation and favour entrapment (not yet described for

396 baleen whales, Goldbogen et al. 2013). Although there was no evidence of bony damage or

397 micro-fracture of the one examined periotic, this cannot be excluded for the other individuals.

398 Any other noise-related damage could neither be ruled out due to the decomposition of the soft

399 tissue structures, nevertheless there is no evidence that for baleen sonar and ground noise could

400 trigger more than non-lethal behavioural and temporary effects (Goldbogen et al. 2013). The

401 strongest argument against this hypothesis is that whales died synchronously along hundreds of

402 kilometres of shore line and at least five different sources of carcasses were identified (see

403 discussion on drift models), which could only be explained by a large number of blastings along

404 the coast during a very restricted time period. The study carried out by SERNAPESCA (Fiscalía

405 de Aysén, 2015; Ulloa et al., 2016, available upon request from SERNAPESCA authorities) based

406 on partial necropsies of two whales in late May 2015, found no evidence of any trauma or human

407 interaction. The whales were already in decomposition stage 3 to 4 and class 1 of taphonomic

408 classes used here. 
410 lobster Munida gregaria (MacKenzie \& Harwood, 2014), an important prey of sei whales

411 (Matthews, 1932). Older reports (Tabeta \& Kanamura, 1970) and recent observations by boat

412 crews (pers. comm. Keri-Lee Pashuk, 2015) indicate that squat lobster abundance fluctuates

413 strongly and can reach extremely high concentrations, especially in Golfo Tres Montes (Tabeta

414 \& Kanamura, 1970). The presence of PST in mytilids from the area and in the whale carcasses

415 and the absence of evidence for other causes of death leaves paralytic shellfish poisoning (PSP)

416 as the most probable cause of death (Table 6). Although AST was also detected in one of the

417 stomach content samples, it is not believed to be the cause of the MME as it was not detected by

418 the toxin monitoring stations. A mixed assemblage of 40 skeletons from the Miocene in the north

419 of Chile, dominated by rorqual whales and attributed to four recurrent HAB events, shows many

420 similarities to the assemblages described here (Pyenson et al., 2014). The characteristics of the

421 MME and the repetition in the same locality are common features for HAB-mediated mortalities

422 (Brongersma-Sanders, 1957) (see Table 6, 7). MMEs through PSP in rorquals are thus not a

recent phenomenon in the South East Pacific. Nevertheless, whale bone accumulations and

suggest an increase in the frequency of mortalities (Table 8). Since the early 1990s HABs have

been recorded every year in spring and autumn along the entire Patagonian coast but patterns are

patchy and generally restricted to bays and fjords. The same is true the coast of the Northeast

Pacific where HAB events have been increasing in strength and extension (Cook et al., 2015).

This MME coincided with increased mortality of baleen whales along the west coast of North America in 2015 (NOAA, 2015b), and with the most extended and longest lasting HAB event registered there (NOAA, 2015c). A positive correlation between the occurrence of PST blooms and the ENSO indices in northern and central Patagonia has been shown (Cassis et al., 2002; 
434 and surface temperatures, which in turn are affected by ENSO, was observed in Aysén by Cassis

435 et al., (2002). El Niño events have increased in frequency and strength due to global warming

436 (Cai et al., 2014). A strong El Niño event began to build in September 2014, which became the

437 strongest El Niño of all time (NOAA, 2015a). The calculated cumulative windstress (Fig. 13)

438 suggests that during this period there was an anomalous tendency towards coastal upwelling and

439 associated nutrient delivery. Exceptionally high levels of PST, ten times higher than usual peaks,

440 were reported in March 2015 from the closest monitoring site $120 \mathrm{~km}$ north of the mortality area

441 (Isla Canquenes, Fig. 14).

442 The presence of PST during February 2016 was accompanied by deep red/brown surface

443 water discoloration due to the high abundance of Alexandrium catenella. This harmful algal

444 bloom was coincidental with an unusually large bloom of the same toxic species in the waters

445 around Chiloé island $\left(42^{\circ} \mathrm{S}\right)$ (Hernández et al, 2016). The May 2016 expedition did not observe

446 water discolouration at this location, nevertheless the phytoplankton samples obtained at the

447 mouth of Seno Newman were also positive for PST, indicating that this toxic species can be

448 present in the area for long periods of time during the summer. The PST levels at Isla Canquenes

449 were not elevated in 2016; however, at two sites in the Messier Channel levels four and seven

450 times higher than usual peaks, were measured (Fig. 15) 
452 below a depth of $50 \mathrm{~m}$ to $100 \mathrm{~m}$, they tend not to re-float since hydrostatic pressure compresses decomposition gases (Smith et al., 2015). The bathymetry in the Golfo de Penas area and off the steeply sloping Taitao Peninsula (Fig. 12) requires that the whales that washed ashore all died near the shore. Thus, we conclude that despite common belief (Perrin et al., 2009a) sei whales opportunistically feed close to shore and may even follow their prey into narrow and shallow inlets and channels. This hypothesis is supported by the fact that live Sei whales were observed nearshore in Golfo de Penas and Estero Slight on several occasions (Table 8).

The drift model suggests that the observed carcasses originated from multiple sites. The carcasses found in the two fjordic inlets of Seno Newman and Estero Slight (62\% of the total) probably died not far from where they stranded, either in the Golfo Tres Montes or within the inlets themselves (Figs. 1, 9), since source locations elsewhere in Golfo de Penas or north of Taitao Peninsula do not lead to carcasses in this region (Fig. 12B-D). Although the inlets themselves are not resolved in the drift model, the net seaward surface outflow of a fjord would only allow carcasses to collect toward its head (as observed) if wind and waves in that direction dominated their drift, or if they died close to the site where they were found. Modeled winds were occasionally toward the head of Seno Newman, on March 20 and during April 14 -18, but almost never in the case of Estero Slight (Fig. 16), so it is highly likely that the carcasses found within these inlets were the result of mortality within the inlets themselves. Carcasses from within these inlets could, however, be exported to nearby coastal waters and then distributed around Golfo de Penas as seen in the drift simulations for a source in Golfo Tres Montes (Fig. 12A), so mortality within the inlets of Seno Newman and Estero Slight could have been the source for carcasses found elsewhere in Golfo Tres Montes or Golfo de Penas. 

is similarly unresolvable by the drift model, but it also appears highly likely that these carcasses resulted from mortality within the inlet itself. It is however unclear why dozens of large whales would swim into a narrow inlet which in most parts is only between 2 and $7 \mathrm{~m}$ deep (maximum depth 15 m just inside extremely shallow entrance) (Fig. 17). never led to carcasses on or to the north of Taitao Peninsula, therefore the observed carcasses on the exposed shoreline in that region (Estero Cono) likely originated close to shore, either locally or to the north. The carcasses found between the southern end of Golfo de Penas and $49^{\circ} \mathrm{S}$ either died very close to where they washed ashore or were transported from the large concentrations in

Golfo de Penas by clockwise flow within the gulf. The five whales between $49^{\circ} \mathrm{S}$ and $51^{\circ} \mathrm{S}$ probably died locally. individuals, some even near to the shore of Golfo de Penas and Estero Slight (Table 8). Therefore, the number of whales that have been exposed to toxins could be considerable. It has been calculated that less than $10 \%$ of the gray whales that are estimated to die each year in the eastern North Pacific are washed ashore, while most sink and do not resurface (Rugh et al., 1999). Assuming a similar ratio, our observations may greatly underestimate the actual magnitude of this mortality event. Many whales may have sunk and never re-surfaced, and a significant number of carcasses may have been washed ashore on the many remote beaches that could not be surveyed due to adverse weather conditions. Others may have been destroyed by wave action from winter storms on the high-energy rocky shores that dominate the area. 
497 considering the number of carcasses, and their temporal and spatial extent. This ranged from two 498 years (gray whales; Gulland et al., 2005) to a few weeks (Humpback whales of cape Code;

499 Geraci, 1989). To determine the time span of this MME, the classification of carcasses was

500 carried out following the disarticulation sequence proposed by Schäfer (1972).

Time since death and time of transportation at sea of the carcass are slightly different in

502 terms of articulation and state of decomposition. Following Schäfer (1972), the first breakage of

503 the outer tissue of a carcass at sea should occur within a week to a month, although in Chilean

504 Patagonia the time span could be a little greater due to the low temperature. In addition, some carcasses could have drifted for some weeks, arrived intact on shore, and then decayed more rapidly exposing the bones, while other carcasses could have floated longer until skull, tail and

507 limbs were disarticulated, but decayed more slowly due to the colder water temperatures. This was in agreement with the comparisons of the disarticulation of carcasses in the field assessed through the photographs of the different expeditions to the same area (Estero Slight, in April and May 2015). Nevertheless, at the present assemblage, the time until the bones were exposed was extended from 1 to around 3 months (class 1) and time of disarticulation was shifted from 3 to 6 months (class 2), due to the low average temperature in the study area. 
513 Considering available information on MMEs time scales, it is reasonable to suppose this 514 event occurred over a time span of approximately three to maximum six months (November 5152014 to April 2015). Nevertheless, the record of other crews (Table 2) and modeled 516 oceanographic conditions (see "Carcass drift and potential source locations", above) point to the 517 beginning of the die off around February at Golfo de Penas. Thus the class 2 carcasses would 518 indicate another pulse of corpses arriving at the same area in a different taphonomic condition, 519 which could suggest: a) longer drift time/distance transport; b) equal arrival but different time of 520 death; or c) higher energy environment. The classification of "time at sea" analysis suggested 521 that drift time was in its majority the same with a similar proportion of class a (short drift 522 time/distance). The analysis of the anatomic positions suggests the allochthonous nature of the 523 deposits in all assemblages (see Pyenson et al., 2014). Only two carcasses were found in a dorsal 524 up position which suggests live stranding.

The average density of Golfo Tres Montes assemblages is equivalent to one third of the 526 density calculated for Cerro Ballena, a Late Miocene ( 9 m.y.a.) fossil red tide linked assemblage of northern Chile (3000/km², Pyenson et al., 2014) (Table 5). However, this

528 difference is likely to have a sampling bias since in Golfo Tres Montes and Golfo de Penas we 529 could only could the carcasses along the coastline, but not on the seafloor. 
1. The whales died at sea, close to where they beached. About $90 \%$ of the whales died during one MME (94.7\% for time since death and $87 \%$ for time at sea analysis), most probably between February and April 2015. No major mortality has occurred in the same area in 2016, but mortalities in other areas cannot be excluded (see Fig. 15 for 2016 toxin levels).

2. Since it is likely that all or most of the affected whales were sei whales, the documented mortality may represent a significant increase over the usual death rate of Southern Hemisphere sei whales (Reilly et al., 2008). If the frequency and magnitude of MMEs increase due to climate change this would have a significant impact on the local population and threaten the recovery of this endangered species, which in the Southern Hemisphere was reduced by whaling from about 100,000 to 24,000 individuals by 1980 (Perrin et al., 2009a).

3. This MME and historical data suggest that, at least during years with abundant squat lobsters, the Golfo de Penas is one of the most important feeding grounds for sei whales, hosting the largest and densest known sei whale aggregations outside the polar regions.

1. The MME reported herein and its probable connection to El Nino-caused red tide events throughout the eastern Pacific could indicate that marine mammals are among the first oceanic megafauna victims of global warming. 
547

\section{Acknowledgements}

We particularly thank the organizers and participants of the expedition organized by the Chilean Fisheries Service (SERNAPESCA), especially B. Caceres, G. Garrido, M. Ulloa, F. Viddi, J. Acevedo, T. García, C. Calderón and L. Bedriñana. Thanks also to R. Brownell, N. Pyenson, L. Pastene, E. Poulin, F. Beaujot, U. Pörschmann, P. Pascoe, S. Kraft, K.-L. Pashuk and V. Beasley. Thanks to Bidema PDI, Fiscalía de Aysén and Armada de Chile for field support. We are thankful to many more people for assisting with field-work, technical support and logistics, for sharing or facilitating data and information, and for discussions. This is publication number 134 of Huinay Scientific Field Station.

\section{References}

Aguayo-Lobo A. 1974. The whale problem: a status report. Cambridge, Massachusetts: Harvard University Press.

Anonymous. 2015. Report of the second workshop on mortality of Southern right whales (Eubalaena australis) at Península Valdés, Argentina. Report SC/66a/Rep/9 presented to the Scientific Committee meeting, San Diego, 20th May - 4th June. 
557 Ardhuin F, Marié L, Rascle N, Forget P, and Roland A. 2009. Observation and estimation of Lagrangian, Stokes, and Eulerian currents induced by wind and waves at the sea surface. Journal of physical oceanography 39:2820-2838.

Baker CS, and Clapham PJ. 2004. Modelling the past and future of whales and whaling. Trends in Ecology \& Evolution 19:365-371.

Breivik Ø, Allen A, Maisondieu C, Roth JC, and Forest B. 2012. The leeway of shipping containers at different immersion levels. Ocean Dynamics 62:741-752.

Behrensmeyer, AK. 1973. The taphonomy and paleoecology of Plio-Pleistocene vertebrate assemblages east of Lake Rudolf, Kenya. Harvard University.

Brongersma-Sanders M. 1957. Mass mortality in the sea. Geological Society of America Memoirs 167:941-1010.

Cai W, Borlace S, Lengaigne M, van Rensch P, Collins M, Vecchi G, Timmermann A, Santoso A, McPhaden MJ, Wu L, England MH, Wang G, Guilyardi E, and Jin F-F. 2014. Increasing frequency of extreme El Niño events due to greenhouse warming. Nature Climate Change 4:111-116. 10.1038/nclimate210

Cassis D, Muñoz P, and Avaria S. 2002. Variación temporal del fitoplancton entre 1993 y 1998

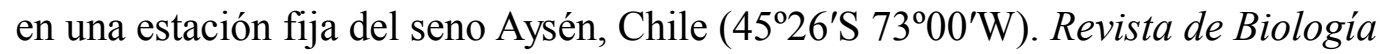
Marina y Oceanografia 37:43-65.

Clapham PJ, Young SB, and Brownell RL. 1999. Baleen whales: conservation issues and the status of the most endangered populations. Mammal review 29:37-62. 
Cook PF, Reichmuth C, Rouse AA, Libby LA, Dennison SE, Carmichael OT, Kruse-Elliott KT, Bloom J, Singh B, Fravel VA, Barbosa L, Stuppino JJ, Van Bonn WG, Gulland FMD, and Ranganath C. 2015. Algal toxin impairs sea lion memory and hippocampal connectivity, with implications for strandings. Science 350:1545-1547. 10.1126/science.aac5675

Coughran DK, Gales NJ, and Smith HC. 2013. A note on the spike in recorded mortality of humpback whales (Megaptera novaeangliae) in Western Australia. Journal of Cetacean Research and Management 13:105-108.

D'Agostino VC, Hoffmeyer MS, Almandoz GO, Sastre V, and Degrati M. 2015. Potentially toxic Pseudo-nitzschia species in plankton and fecal samples of Eubalaena australis from Península Valdés calving ground, Argentina. Journal of Sea Research 106:39-43. DOI: 10.1016/j.seares.2015.09.004

Dalebout M, Robertson K, Frantzis A, Engelhaupt D, Mignucci- Giannoni A, RosarioDelestre R, Baker CS. 2005. Worldwide structure of mtDNA diversity among Cuvier's beaked whales (Ziphius cavirostris): implications for threatened populations. Molecular Ecology $14: 3353-3371$.

Dee DP, Uppala SM, Simmons AJ, Berrisford P, Poli P, Kobayashi S, Andrae U, Balmaseda MA, Balsamo G, Bauer P, and Bechtold P. 2011. The ERA-Interim reanalysis: Configuration and performance of the data assimilation system. Quarterly Journal of the Royal Meteorological Society 137:553-597. 
Doucette GJ, Cembella AD, Martin JL, Michaud J, Cole TVN, and Rolland RM. 2006. Paralytic shellfish poisoning (PSP) toxins in North Atlantic right whales Eubalaena glacialis and their zooplankton prey in the Bay of Fundy, Canada. Marine Ecology Progress Series 306:303-313.

Durbin E, Teegarden G, Campbell R, Cembella A, Baumgartner MF, and Mate BR. 2002. North Atlantic right whales, Eubalaena glacialis, exposed to paralytic shellfish poisoning (PSP) toxins via a zooplankton vector, Calanus finmarchicus. Harmful Algae 1:243-251.

Fire SE, Wang Z, Berman M, Langlois GW, Morton SL, Sekula-Wood E, and Benitez-Nelson, CR. 2010. Trophic transfer of the harmful algal toxin domoic acid as a cause of death in a minke whale (Balaenoptera acutorostrata) stranding in southern California. Aquatic Mammals, 36(4):342-350.

Fiscalía de Aysen. 2015. Official request SIAC nr 460428815 for report, Hucke-Gaete R, Viddi F, Cassis D, Bedriñana L, Häussermann V, Pérez-Alvarez MJ, Horwitz FE, Gutstein CS, Garrido-Toro G, Cáceres B, Aguayo A, Ulloa M. Inédito. Informe técnico sobre la mortalidad masiva de ballenas en Puerto Slight y Caleta Buena, Golfo de Penas, Región de Aysén (expedición de mayo 2015).

Försterra G. 2009. Ecological and Biogeographical Aspects of the Chilean Fjord Region, p. 6176. In: Häussermann, V. \& Försterra, G. (eds): Marine Benthic Fauna of Chilean Patagonia, Nature in Focus, Puerto Montt, 1000 pp. 
615 Försterra G, Häussermann V and Laudien J. In press. Animal forests in the Chilean fjords:

616

617

618

619

620

621

622

623

624

625

626

627

628

629

630

631

632

633

634

635 discoveries, perspectives and threats in shallow and deep waters. In: Rossi S, Bramanti

L, Gori A, Orejas Saco del Valle C (eds.): Marine animal forests - The Ecology of

Benthic Biodiversity Hotspots. Springer International Publishing.Geraci JR, Anderson

DM, Timperi RJ, Early GA, Prescott JH, and Mayo CA. 1989. Humpback whales

(Megaptera novaeangliae) fatally poisoned by dinoflagellate toxin. Journal of the

Fisheries Research Board of Canada 46:1895-1898.

Geraci JR, and Aubin DJ. 1977 Mass stranding of the long-finned pilot whale, Globicephala melaena, on Sable Island, Nova Scotia. Journal of Fisheries Research Board of Canada 34, 2193 - 2196. DOI 10.1139/f77-288.

Geraci JR, and Lounsbury VJ. 2005. Marine Mammals Ashore: A Field Guide for Strandings Second Edition. National Aquarium in Baltimore. Baltimore, MD.

Geraci JR, Anderson, DM, Timperi RJ, St. Aubin DJ, Early GA, Prescott JH, and Mayo CA. 1989. Humpback whales (Megaptera novaeangliae) fatally poisoned by dinoflagellate toxin. Canadian Journal of Fisheries and Aquatic Sciences, 46:1895-1898.

Gilmore RM. 1971. Observations on marine mammals and birds off the coast of southern and central Chile, early winter 1970. Antarctic Journal of the United States 6:10-11.

Goldbogen J.A, Southall B L, DeRuiter SL, Calabokidis J, Friedlaender AS, Hazen E L, Falcone EA, Schorr GS, DouglasA, Moretti D, Kyburg C, McKenna M F, Tyack PL. 2013. Blue whales respond to simulated mid-frequency military sonar. Proceedings of the Royal Society - B Biological Sciences 280: 20130657. 
636 González H, Calderón M, Castro L, Clement A, Cuevas L, Daneri G, Iriarte J, Lizárraga L, 637 Martínez R, and Menschel E. 2010. Primary production and plankton dynamics in the 638 Reloncaví Fjord and the Interior Sea of Chiloé, Northern Patagonia, Chile. Marine 639 640 641 Ecology Progress Series 402:13-30.

Gulland FMD, Pérez-Cortés H, Urban J, Rojas-Bracho L, Ylitalo G, Weir J, Norman SA, Muto

644 645 646 647 648 649 MM, Rugh DJ, Kreuder C, and Rowles T. 2005. Eastern North Pacific gray whale (Eschrichtius robustus) unusual mortality event, 1999-2000. NOAA Technical Memorandum NMFS-AFSC-150. p 44.

Guzmán L, Pacheco H, Pizarro G, and Alarcón C. 2002. Alexandrium catenella y veneno paralizante de los mariscos en Chile. In: Sar E, Ferrario M and Reguera B. (eds). Floraciones Algales Nocivas en el Cono Sur Americano, 235-255.Guzman L \& Pizarro G. 2014. Effects of the El Niño-Southern Oscillation (ENSO) teleconnections on the abundance of micro-phytoplankton and Alexandrium catenella, in Southern Chile. Presented at the ICHA 16 conference in Wellington, New Zealand. 
650

651

652

653

654

655

656

657

658

659

660

661

662

663

664

665

666

667

668

669

670

671

Häussermann V, and Försterra G. 2005. Distribution patterns of Chilean shallow-water sea anemones (Cnidaria: Anthozoa: Actiniaria, Corallimorpharia); with a discussion of the taxonomic and zoogeographic relationships between the actinofauna of the South East Pacific, the South West Atlantic and Antarctica. P. 91-102. In Arntz WE, Lovrich GA, and Thatje S (eds.): The Magellan-Antarctic connection: links and frontiers at high southern latitudes. Scientia Marina 69 (Suppl 2).Hernández C, Díaz PA, Molinet C, and Seguel M. 2016. Exceptional climate anomalies and northwards expansion of Paralytic Shellfish Poisoning outbreaks in southern Chile. Harmful Algae News 54: 1-2.Holz M, and Simões MG. 2002. Elementos fundamentais de tafonomia, Ed. Universidade, Porto Alegre, p. 231.

Jauniaux T, Charlier G, Desmecht M, Haelters J, Jacques T, Losson B, Van Gompel J, Tavernier J, and Coignoul, F. (2000). Pathological findings in two fin whales (Balaenoptera physalus) with evidence of morbillivirus infection. Journal of comparative pathology, 123(2), 198-201. DOI: 10.1053/jcpa.2000.0395

Ketten DR. 1992. Estimates of blast injury and acoustic trauma zones for marine mammals from underwater explosions In: Kastelein RA, Thomas JA, and Nachtigall PE (eds.): Sensory Systems of Aquatic Mammals (1995) De Spil Publishers, Woerden, The Netherlands, ISBN 90-72743-05-9.

Kraus SD. 1990. Rates and potential causes of mortality in North Atlantic right whales (Eubalaena glacialis). Marine Mammal Science 6(4):278-91.

Large W G, and Pond S. 1981. Open ocean momentum flux measurements in moderate to strong winds. Journal of Physical Oceanography 11: 324-481. 
672 Lefebvre KA, Quakenbush L, Frame E, Huntington KB, Sheffield G, Stimmelmayr G, Bryan A,

673 Kendrick P, Ziel H, Goldstein T, Snyder JA, Gelatt T, Gulland F, Dickerson B, and

674

675

676

677 Verena G. 2016. Prevalence of algal toxins in Alaskan marine mammals foraging in a changing arctic and subarctic environment. Harmful Algae 55: 13-24. DOI: 10.1016/j.hal.2016.01.007

Liebig PM, Taylor T-SA, and Flessa KW. 2003. Bones on the beach: marine mammal taphonomy of the Colorado Delta, Mexico. Palaios 18:168-175.

Liebig PM, Flessa KW, and Taylor SA. 2007 Taphonomic variation despite catastrophic mortality: analysis of a mass stranding of false killer whales (Pseudorca crassidens), Gulf of California, Mexico. Palaios 22, 384 - 391. DOI:10.2110/palo.2005.p05-052r)

MacKenzie AL, and Harwood T. 2014. Grazing on a toxic Alexandrium catenella bloom by the lobster krill Munida gregaria (Decapoda: Galatheoidea: Munididae). Harmful Algae 39:161-164.

Matthews LH. 1932. Lobster-krill. Anomuran crustacean that are the food of whales. Discovery Reports 5:467-484.

Mazzariol S, Centelleghe C, Beffagna G, Povinelli M, Terracciano G, Cocumelli C, Pintore A, Denurra D, Casalone C, Pautasso A, Di Francesco CE, and Di Guardo G. 2016. Mediterranean Fin Whales (Balaenoptera physalus) Threatened by Dolphin MorbilliVirus. Emerging Infectious Diseases, 22(2), 302-305. DOI:

10.3201/eid2202.150882 
692

693

694

695

696

697

698

699

700

701
Molinet C, Lafon A, Lembeye G, Moreno CA. (2003). Patrones de distribución espacial y temporal de floraciones de Alexandrium catenella (Whedon \& Kofoid) Balech 1985, en aguas interiores de la Patagonia noroccidental de Chile. Revista chilena de historia natural, 76(4), 681-698. DOI: 10.4067/S0716-078X2003000400011.

Moore, MJ, Knowlton AR, Kraus SD, Mclellan WA, Bonde RK. 2004. Morphometry, gross morphology and available histopathology in North Atlantic right whale (Eubalaena glacialis) mortalities (1970-2002). Journal of Cetacean Research and Management 6:199-214.

NOAA. 2015a. Climate Dignostics Bulletin. Available at http://www.cpc.noaa.gov/products/analysis_monitoring/enso_advisory/ensodisc.pdf (accessed August, 2015).

NOAA. 2015b. NOAA declares deaths of large whales in Gulf of Alaska an unusual mortality event. Available at http://alaskafisheries.noaa.gov/newsreleases/2015/whalesume082015.htm (accessed August, 2015).

NOAA. 2015c. NOAA fisheries mobilizes to gauge unprecedented West Coast toxic algal bloom. Available at http://www.nwfsc.noaa.gov/news/features/west_coast_algal_bloom/index.cfm (accessed June 2015).

Nowacek DP, Thorne LH, Johnston DW, Tyack PL. 2007 Response of cetaceans to anthropogenic noise. Mammal Review 37:81-115. DOI: 10.1111/j.1365-2907.2007.00104.x.

Pastene LA, and Shimada H. 1999. Report of a sighting survey in Chile's exclusive economic zone with comments on sei whale distribution. Anales del Instituto de la Patagonia, Serie Ciencias Naturales 27:51-62. 
715 Peltier H, Dabin W, Daniel P, van Canneyt O, Dorémus G, Huon M, and Ridoux V. 2012. The significance of stranding data as indicators of cetacean populations at sea: Modelling the drift of cetacean carcasses. Ecological Indicators 18:278-290.

Perrin WF, Würsig B, and Thewissen JGM. 2009a. Encyclopedia of marine mammals. London: Academic Press.

Perrin WF, Mead JG, and Brownell JRL. 2009b. Review of the evidence used in the description of currently recognized cetacean subspecies. U.S. Department of Commerce, National Oceanic and Atmospheric Administration, National Marine Fisheries Service, Southwest Fisheries Science Center.

Pierce SD, Barth JA, Thomas RE, and Fleischer GW. 2006. Anomalously warm July 2005 in the northern California Current: Historical context and the significance of cumulative wind stress. Geophysical Research Letters 33 DOI: 10.1029/2006GL027149.

Pizarro G, Garrido C, Cárdenas C, Frangópulos M, Alarcón C, Guzmán L, Zamora C, and Pacheco H. 2011. Spatial distribution of Alexandrium catenella and paralytic toxins in the plankton and shellfishs between Penas Gulf and Trinidad Channel (Spring 2008). Ciencia y Tecnologia del Mar 34:5-24.

Pyenson ND, Gutstein CS, Parham JF, Le Roux JP, Chavarría CC, Little H, Metallo A, Rossi V, Valenzuela-Toro AM, Velez-Juarbe J, Santelli CM, Rogers DR, Cozzuol MA, and Suárez ME. 2014. Repeated mass strandings of Miocene marine mammals from Atacama Region of Chile point to sudden death at sea. Proceedings of the Royal Society B-Biological Sciences 281:20133316. DOI: 10.1098/rspb.2013.3316 
Reilly SB, Bannister JL, Best PB, Brown M, Brownell Jr. RL, Butterworth DS, Clapham PJ, Cooke J, Donovan GP, Urbán J, and Zerbini AN. 2008. The IUCN Red List of Threatened Species. Version 2015.2. Available at www.iucnredlist.org (accessed 05 September 2015).

Rowntree VJ, Uhart MM, Sironi M, Chirife A, Di Martino M, La Sala L, Musmeci L, Mohamed N, Andrejuk J, McAloose D, Sala JE, Carribero A, Rally H, Franco M, Adler FR, Brownell Jr. RL, Seger J, Rowles T. 2013. Unexplained recurring high mortality of southern right whale Eubalaena australis calves at Península Valdés, Argentina. Marine Ecology Progress Series 493:275-289. DOI: 10.3354/meps10506

Rugh DJ, Muto M, Moore S, and DeMaster D. 1999. Status review of the eastern north Pacific stock of gray whales: US Department of Commerce, National Oceanic and Atmospheric Administration, National Marine Fisheries Service, Alaska Fisheries Science Center.

Schäfer, W. 1972. Ecology and Palaeoecology of Marine Environments. The University of Chicago Press, Chicago, 568 pp.

Shimizu Y, Ohishi K, Suzuki R, Tajima Y, Yamada T, Kakizoe Y, Bando T, Fujise Y, Taru H, Murayama T, and Maruyama T. Amino acid sequence variations of signaling lymphocyte activation molecule and mortality caused by morbillivirus infection in cetaceans. Microbiology and immunology, 57(9), 624-632.

Simões MG, \& Holz M. (2004). Tafonomia: processos e ambientes de fossilização.In: Carvalho, I. S. de (ed) Paleontologia, Rio de janeiro:Interciência 19-45.

Simmonds MP, and Isaac SJ. 2007. The impacts of climate change on marine mammals: early signs of significant problems. Oryx 41:19-26. 
758 Skamarock, WC, Klemp JB. 2008. A time-split nonhydrostatic atmospheric model for weather research and forecasting applications. Journal of Computational Physics 227: 34653485.

Smith CR, Glover AG, Treude T, Higgs ND, and Amon DJ. 2015. Whale-fall ecosystems: recent insights into ecology, paleoecology, and evolution. Marine Science 7:571-596. Suárez B, and Guzmán L. 2005. Floraciones de algas nocivas: mareas rojas y toxinas marinas. Editorial universitaria: 80pp.

Southall BL, Bowles AE, Ellison WT, Finneran JJ, Gentry RL, Greene CR, Charles R, Kastak, D, Ketten DR, Miller JH, Nachtigall PE, Richardson WJ, Thomas JA, and Tyack, PL. 2009. Marine mammal noise exposure criteria: Initial scientific recommendations. The Journal of the Acoustical Society of America, 125(4): 2517-2517. DOI: 10.1121/1.4783461

Tabeta O, and Kanamura S. 1970. On the post larva of Munida gregaria (Crustacea, Galatheida) in Penas Bay, Chile, with reference to mass occurrence in 1969. Science Bulletin of the Faculty of Agriculture 24:227-230.

Terrametrics. 2015. Google earth 7.1.5.1557. Available at http://www.earth.google.com (accessed October 2015). 
774 Thiel M, Macaya EC, Acuña E, Arntz WE, Bastias H, Brokordt K, Camus PA, Castilla JC,

Castro LR, Cortés M, Dumont CP, Escribano R, Fernandez M, Gajardo JA, Gaymer CF, Gomez I, González AE, González HE, Haye PA, Illanes JE, Iriarte JL, Lancellotti DA, Luna-Jorquera G, Luxoro C, Manriquez PH, Marín V, Muñoz P, Navarrete SA, Perez E, Poulin E, Sellanes J, Sepúlveda HH, Stotz W, Tala F, Thomas A, Vargas CA, Vasquez J, and Vega JMA. 2007. The Humboldt Current System of northern and central Chile. Oceanography and Marine Biology: An Annual Review 45:195-344.

Toots H, 1965. Sequence of disarticulation in mammalian skeletons. Contributions to Geology University of Wyoming, 4(1):37-39.

Torres R, Silva N, Reid B, and Frangopulos M. 2014. Silicic acid enrichment of subantarctic surface water from continental inputs along the Patagonian archipelago interior sea (4156 S). Progress in Oceanography 129:50-61.

Van Bressem MF, Duignan PJ, Banyard A, Barbieri M, Colegrove KM, de Guise S, di Guardo G, Dobson A, Domingo M, Fauquier D. 2014. Cetacean Morbillivirus: Current Knowledge and Future Directions. Viruses. 6(12):5145-5181. DOI:10.3390/v6125145.

Vanderlann ASM and Taggart CT. 2007. Vessel collisions with whales: the probability of lethal injury based on vessel speed. Marine Mammal Science 23(1): 144-156.

Vidal O, Gallo Reynoso JP. 1996. Die offs of marine mammals and sea birds in the gulf of California, México. Marine Mammal Science 12:627-635.

Voorhies MR. 1969. Taphonomy and population dynamics of an early Pliocene vertebrate fauna, Knox County, Nebraska. Contributions to Geology, University of Wyoming Special Paper Nr 1:1-69. 
796 Wallcraft AJ, Metzger EJ, and Carroll SN. 2009. Software Design Description for the HYbrid

Coordinate Ocean Model (HYCOM), Version 2.2. Report no. NRL/MR/7320--09-9166, Naval Research Laboratory, Stennis Space Center, Mississippi, USA.

Wilson C, Sastre AV, Hoffmeyer M, Rowntree VJ, Fire SE, Santinelli NH, Díaz Ovejero S, D'Agostino V, Marón CF, Doucette GJ, Broadwater MH, Wang Z, Montoya N, Seger J, Adler FR, Sironi M, and Uhart MM. 2015. Southern right whale (Eubalaena australis) calf mortality at Península Valdés, Argentina: Are harmful algal blooms to blame? Marine Mammal Science DOI:12263. 10.1111/mms.12263 
Fig. 1: Location of dead whales and skulls found in Chilean Patagonian. Boat track: green (HF24), flight track: blue (HF25) A) Golfo de Penas, B) Golfo Tres Montes, C) Seno Escondido.

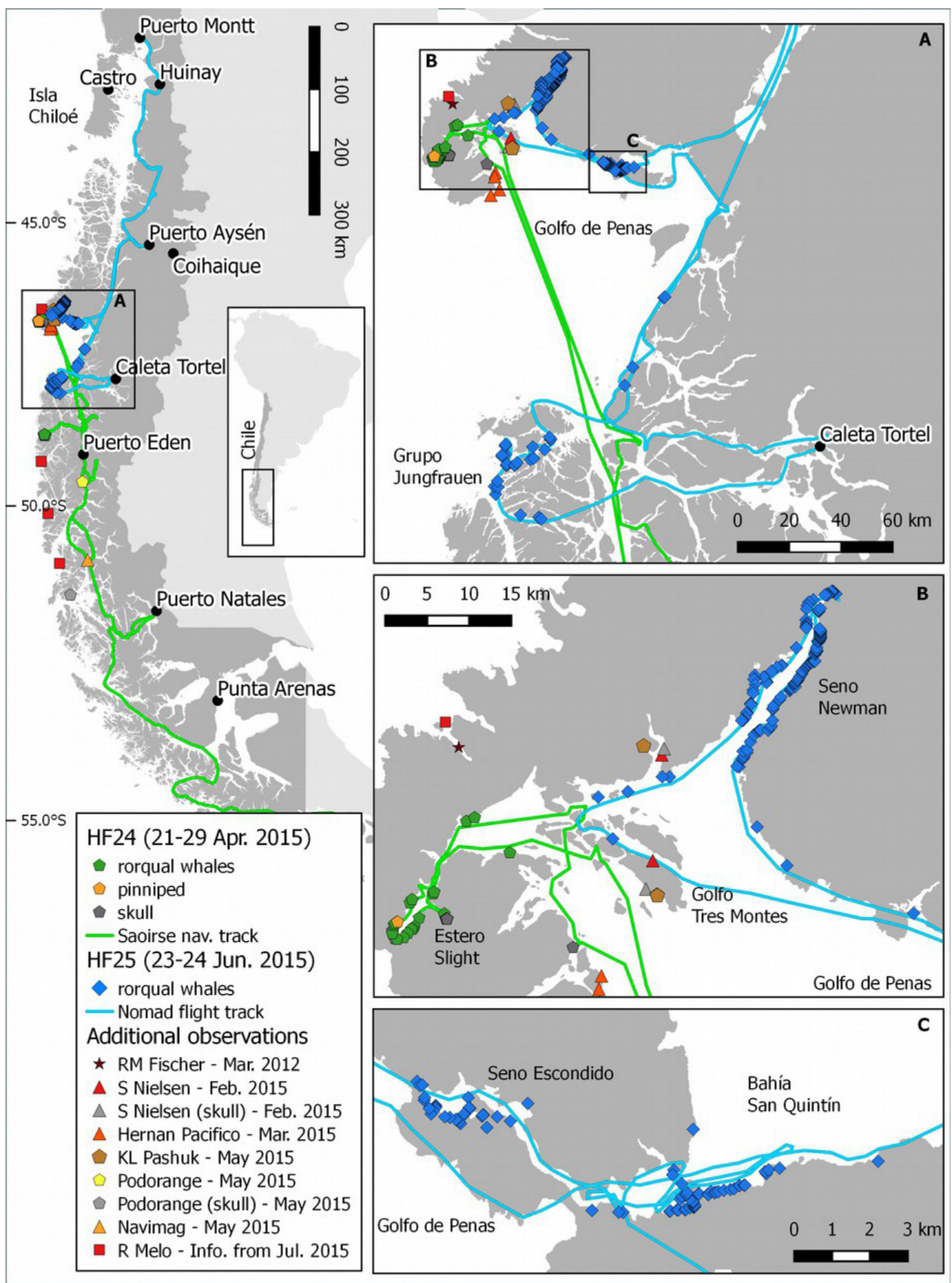


807 Fig. 2: Satellite image (MODIS Aqua) showing the concentration of chlorophyll a on March 23rd, 2015. Areas

808 where most whales were found are circled.

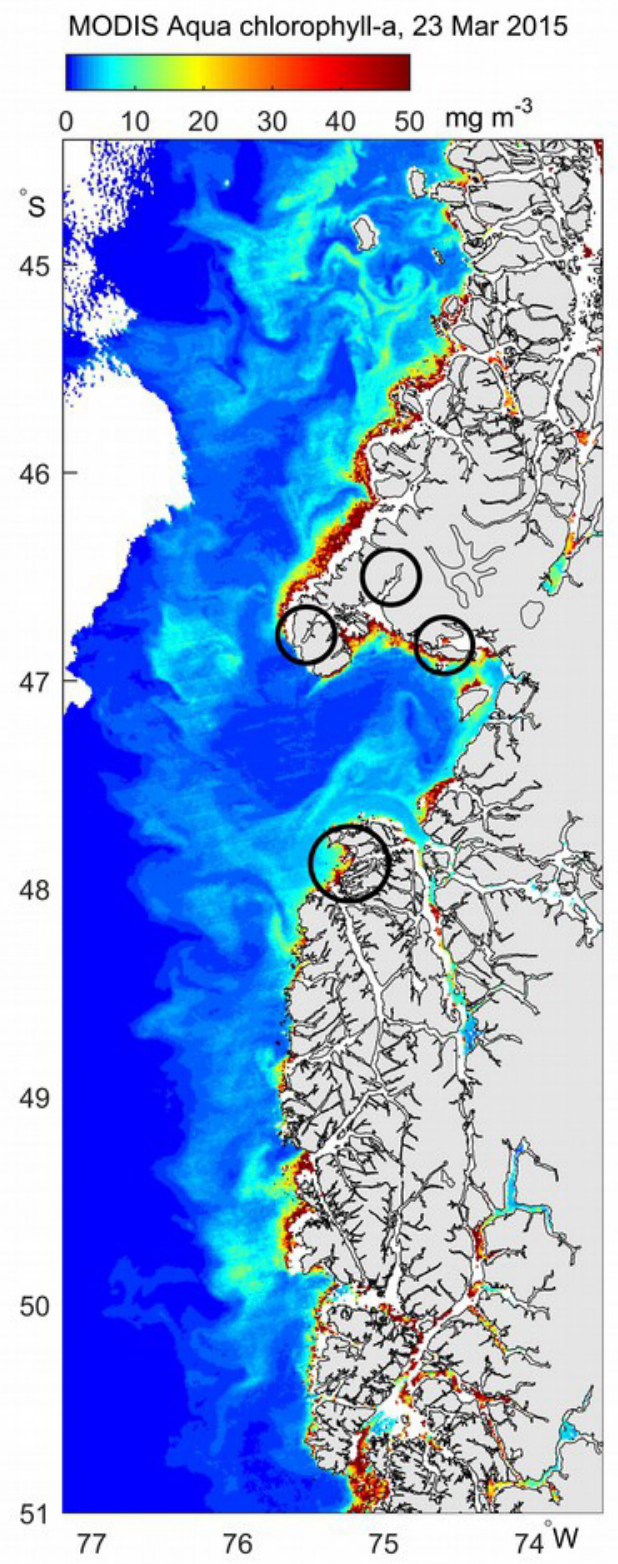

809 Fig. 3: Documented whale carcasses and skeletal remains during a vessel survey in April 21st 2015 in Caleta Buena,

810 Estero Slight. A) and B) skeletal remains C) Recently dead sei whale. Photos: Keri-Lee Pashuk, all rights reserved. 

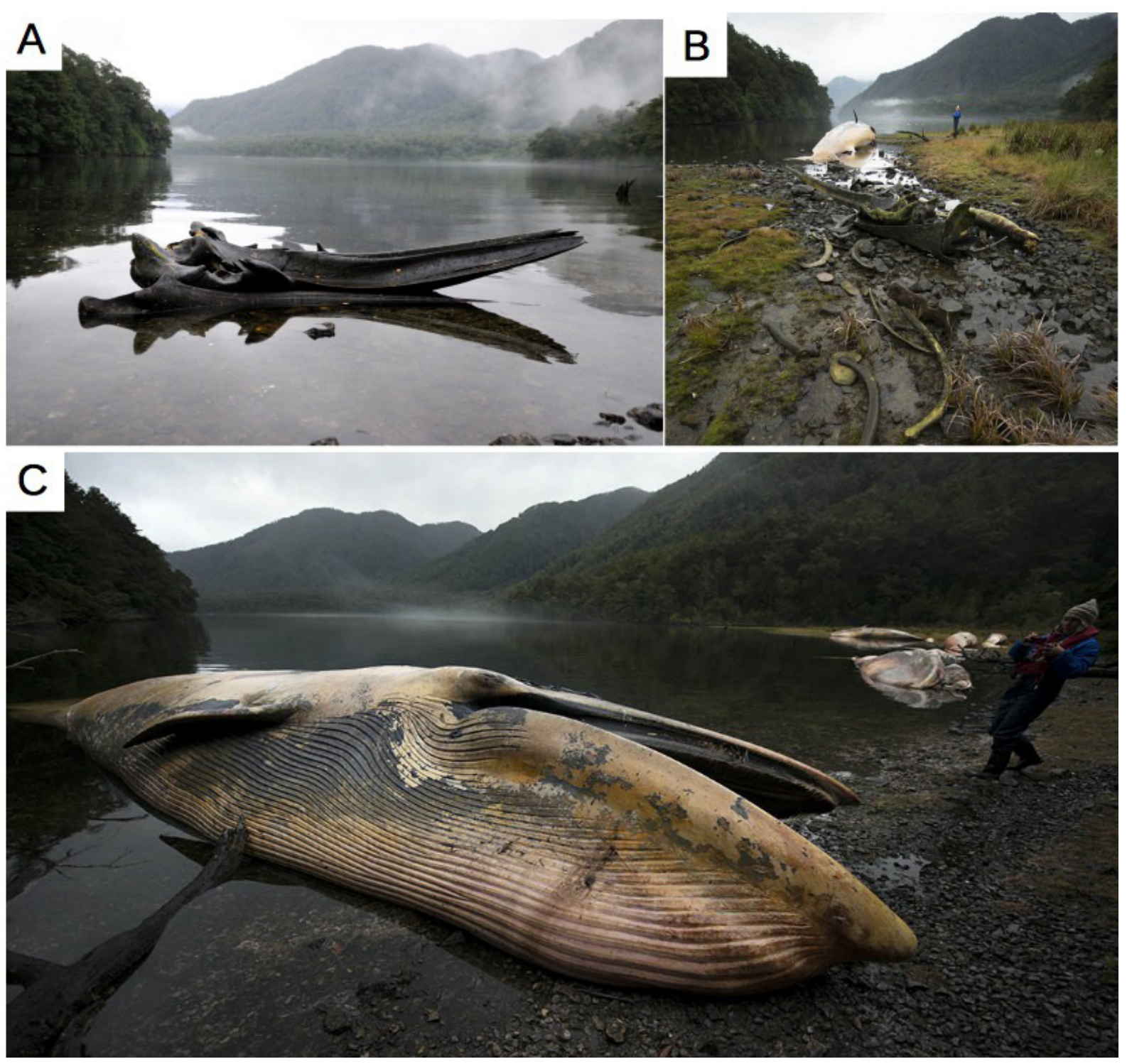
811 Fig. 4: Documented whale carcasses and skeletal remains during an overflight on June 25st 2015,

812 Seno Escondido. The numbers correspond to the whale identification numbers in Table 1. Photos:

813 Vreni Häussermann, all rights reserved.

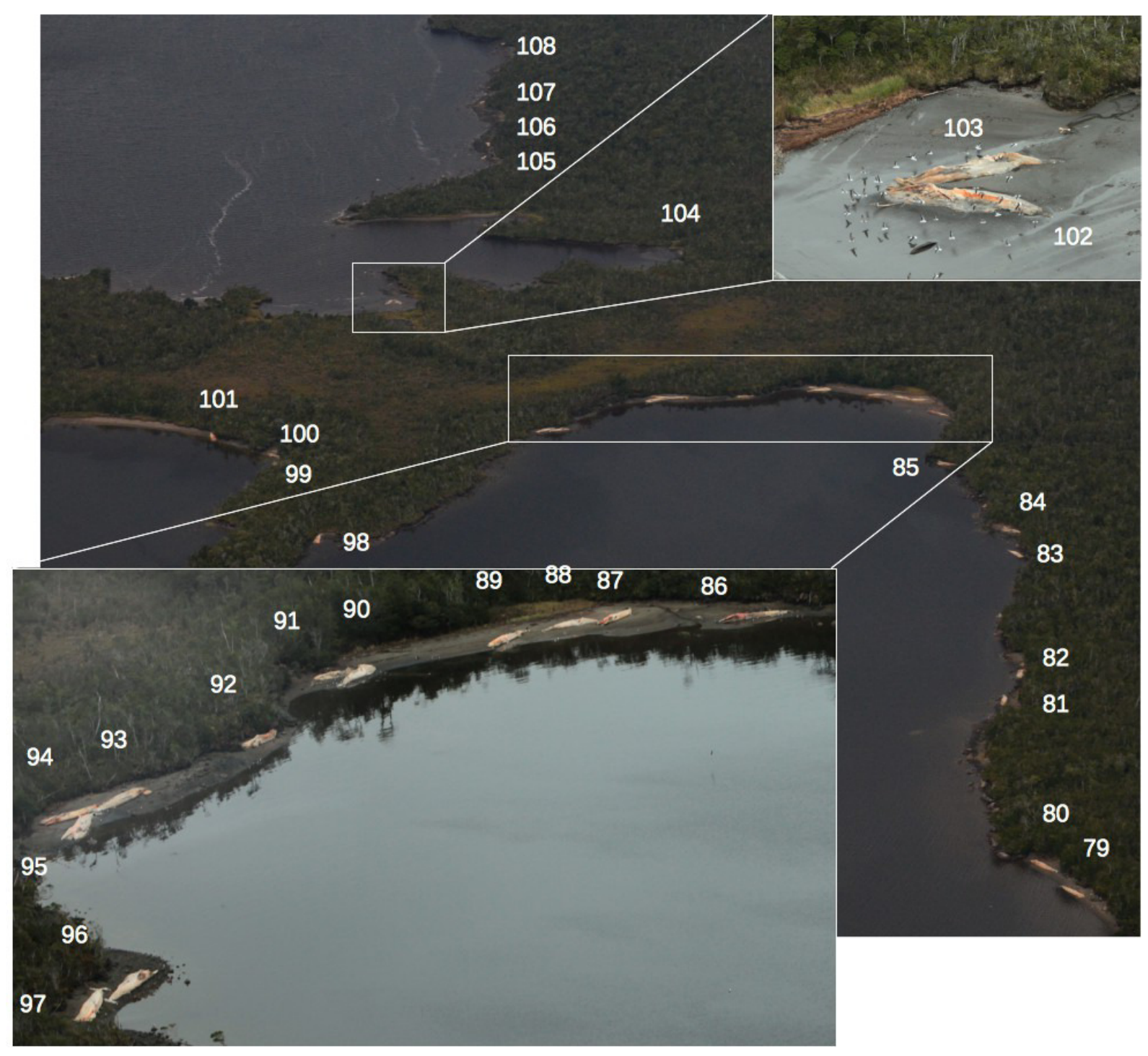


814 Fig. 5: A. A. Satellite image on August 13th 2015, used to count the carcasses along Seno

815 Newman. B-C-D. Detail of the carcasses highlighted in A.
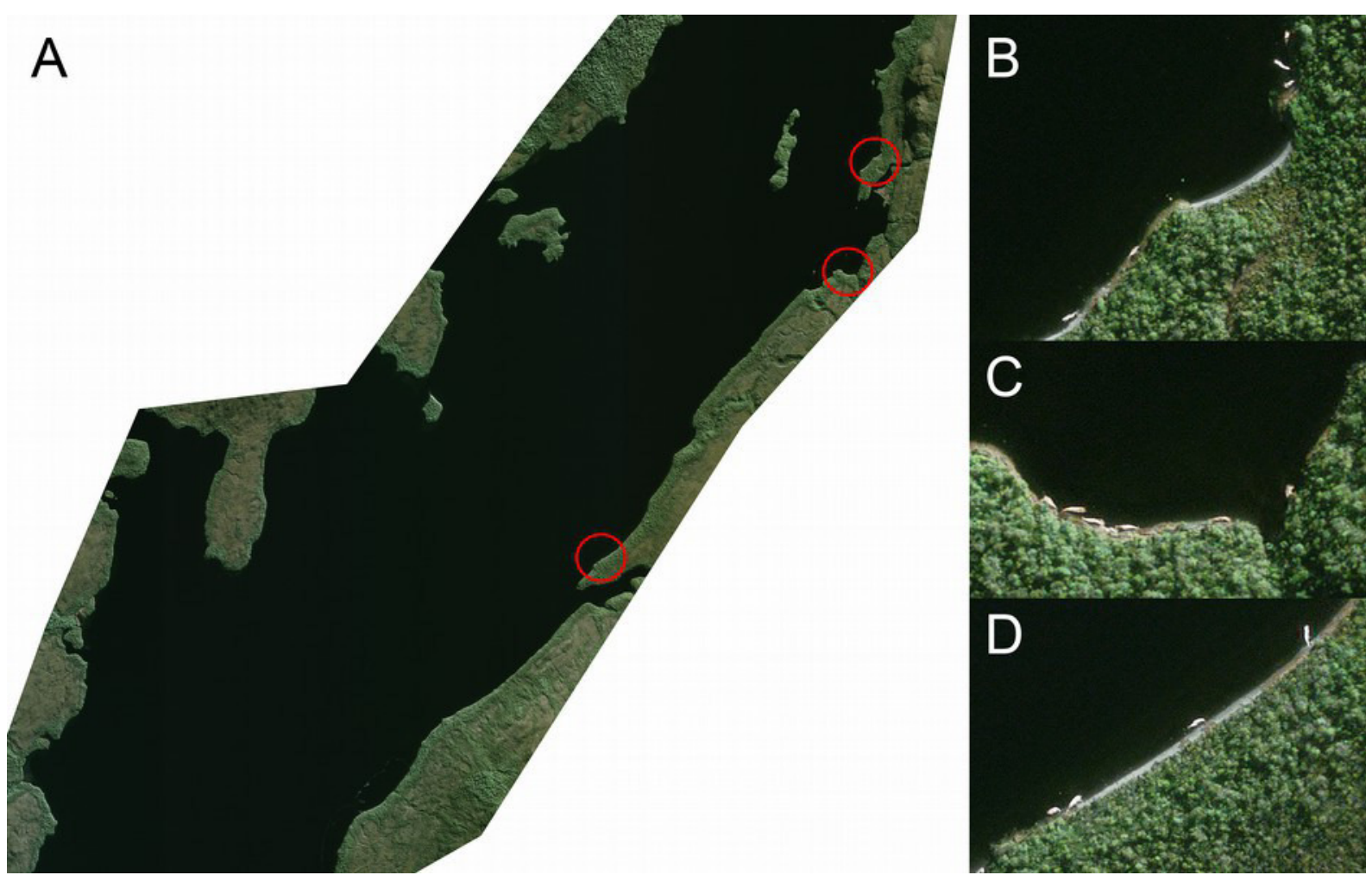
816 Fig. 6: Biostratinomic classification addressing the decomposition/desarticulation of carcasses/skeletal remains

817 assessing to the time since death. A-B) Class 1, carcasses in the lowest to relatively medium state of decomposition,

818 C-D) Class 2, carcasses in a relatively greater state of decomposition, but still maintaining their longitudinal axis,

819 although some bones may be scattered, E-F) Class 3, isolated skeletal remains with no soft tissue.
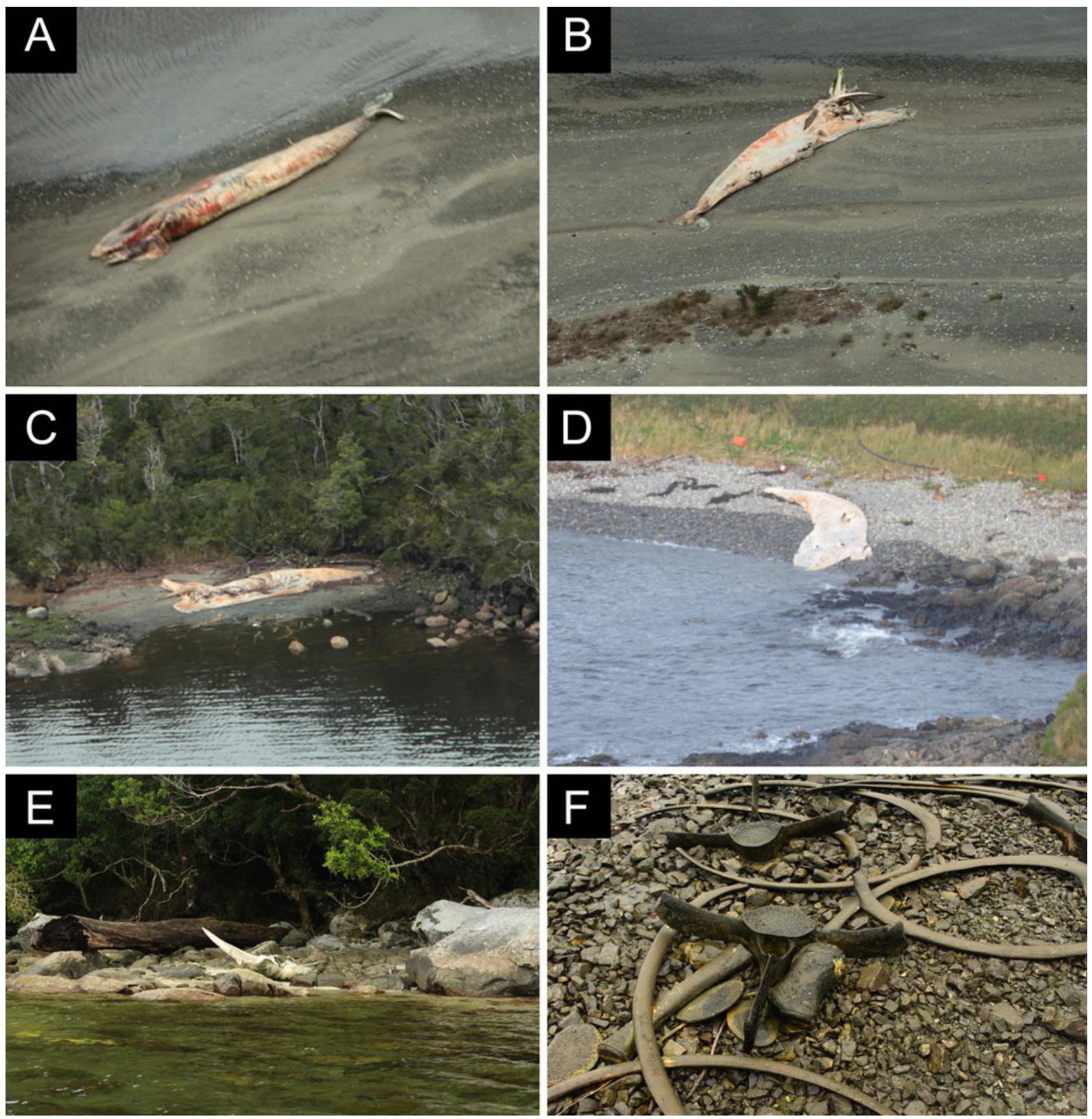

Fig 7: Biostratonomic classification of the location of death of carcasses/skeletal remains A)

821 Carcasses preserving the skull, B) Carcasses lacking the skull. 

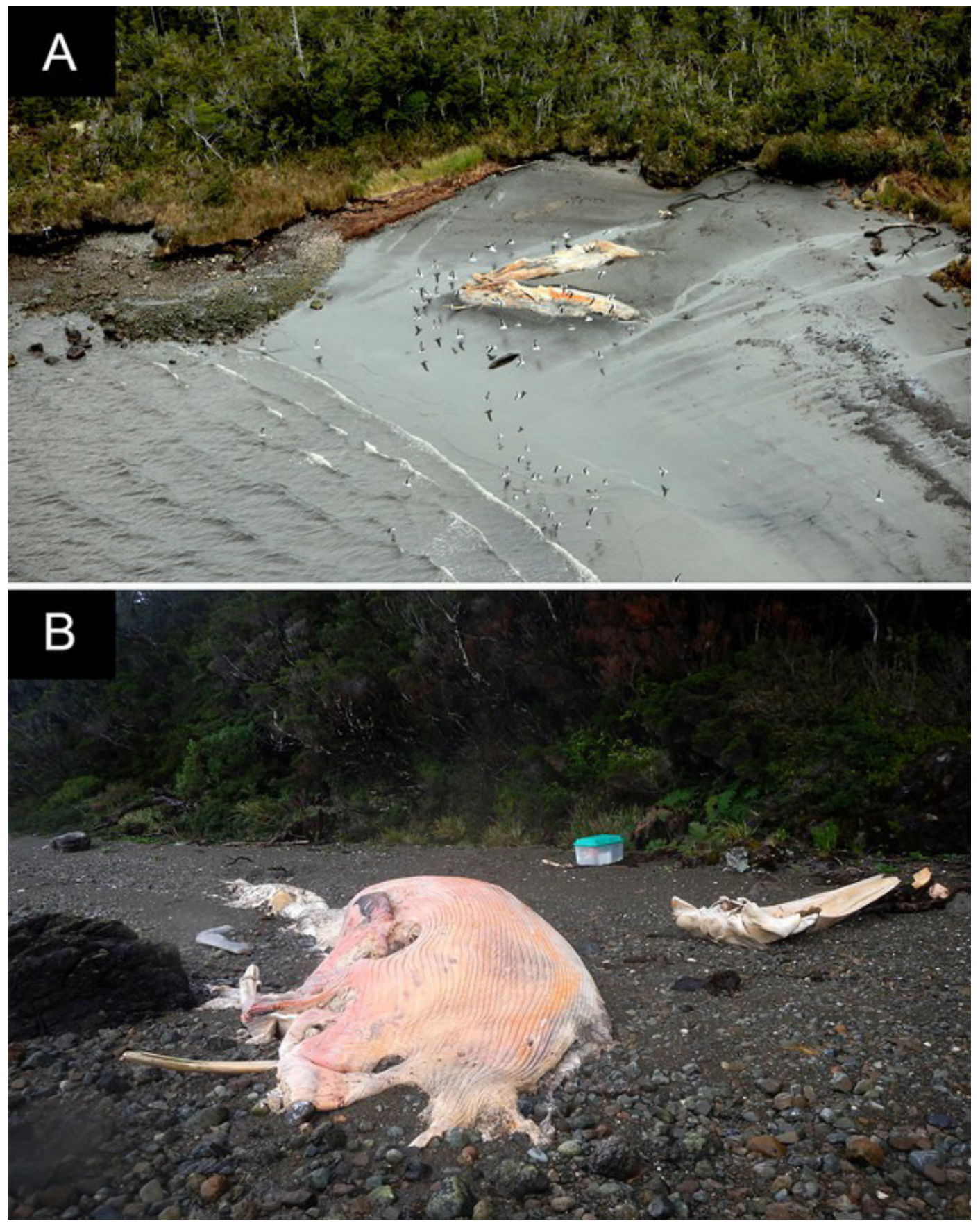

822 Fig. 8: Digital images obtained through computed volumetric tomography (CVT) scanned at

823 Morita Tomography (box of $60 \mathrm{~mm}, 500$ slices). All acoustic anatomical structures of the middle

824 ear (ossicles: stapes), internal ear (cochlea: spiral lamina) and the semicircular canals are seen in perfect condition. 

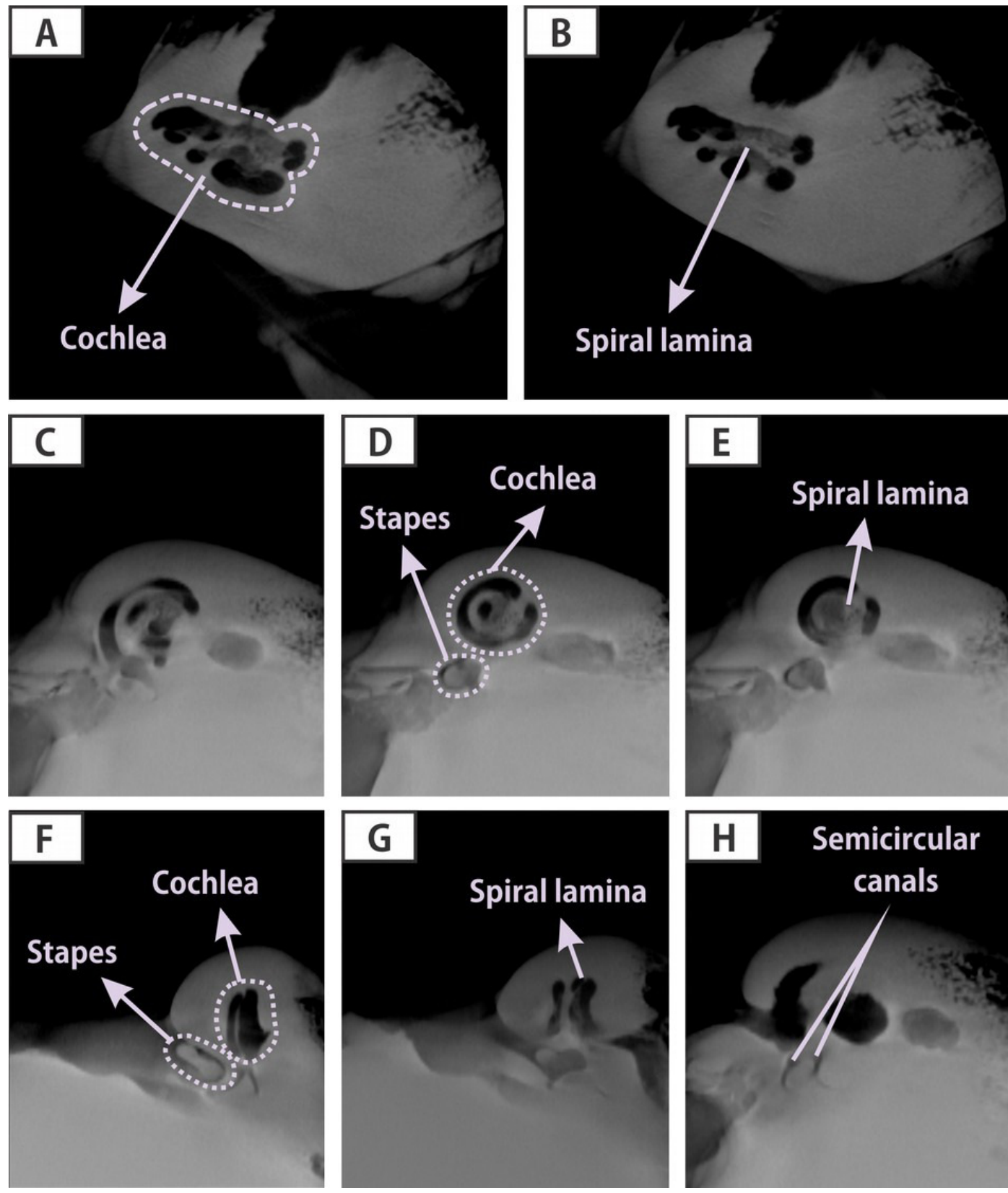

826 Fig. 9: Maps showing the five assemblages of whale carcasses. (A) Golfo de Penas, (B) Seno

827 Escondido, (C) Seno Newman, (D) Estero Slight, (E) Jungfrauen Islands. State of decomposition

828 color-coded: Yellow (state 1; least decomposed, all articulated), orange (state 2, intermediate

829 decomposed), red (state 3; isolated remains). 


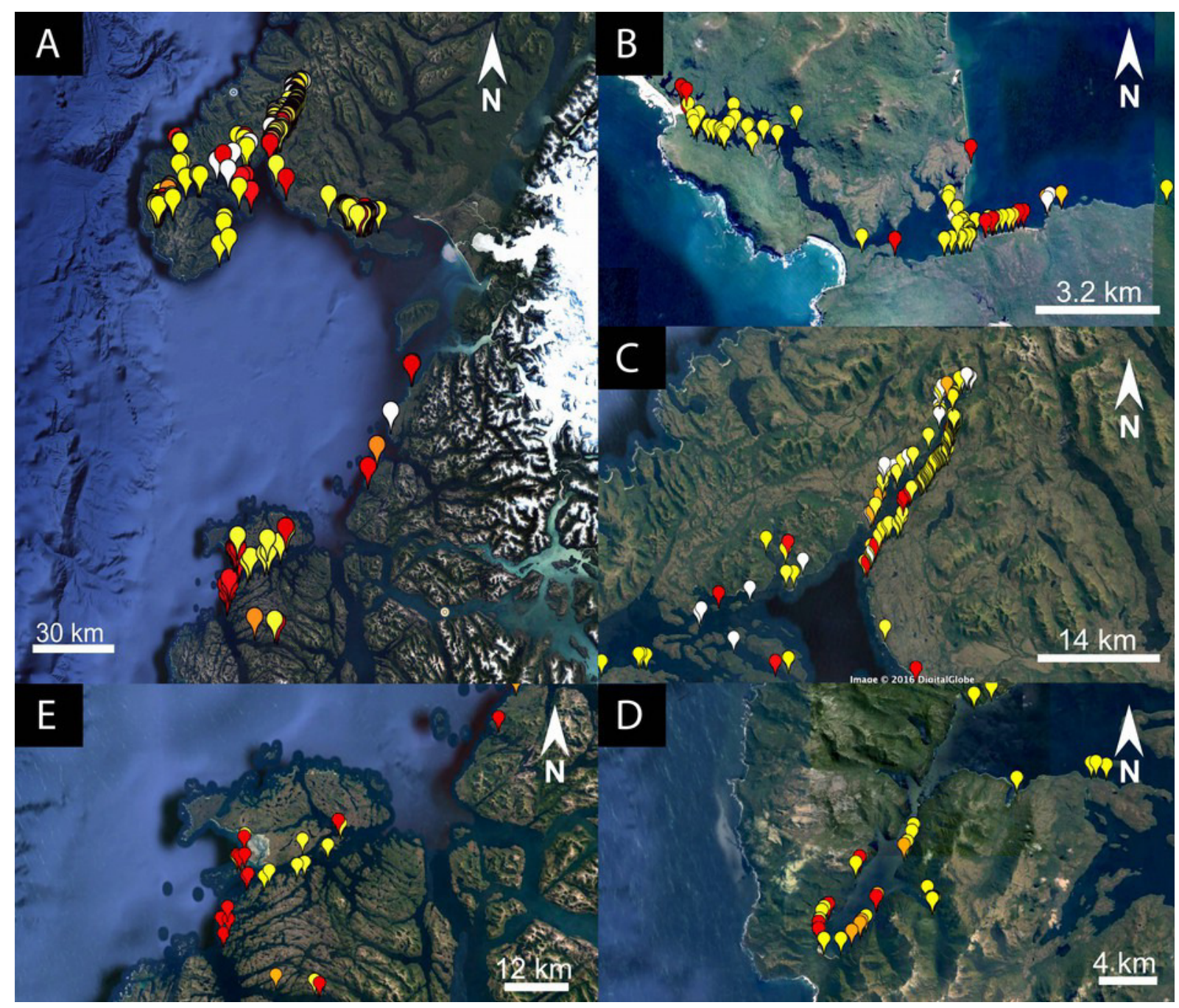


830 Fig. 10: Inflation of the tongue and its implication for whale carcass deposition. A) inflated

831 tongue in a very recently dead sei whale (weeks) indicated by the arrow head (Photo:

832 Brice Monégier, all rights reserved). B) Close-up of the mouth with dislocate mandibles due to

833 the previous inflation of the tongue (arrow head), which is decayed and removed by scavengers.

834 C) Whale carcass seen from the overflight deposited in lateral position and its protuberant

835 inflated tongue (arrow head).
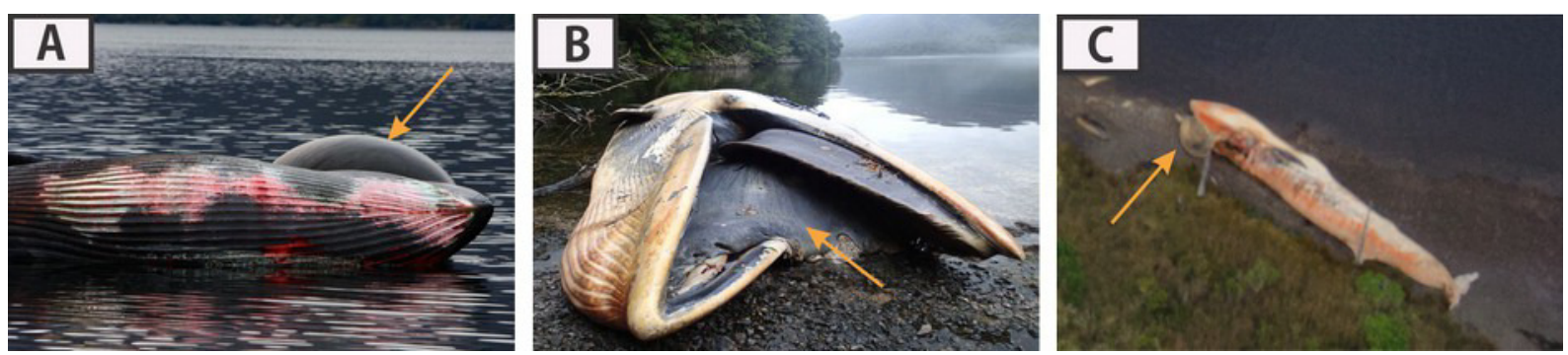
836 Fig. 11: Graphs showing the proportion of the total classified carcasses in the biostratonomic

837 analysis. A) Time since death, B) Time since death, combining Class 1 and 2, C) location of

838 death, D) Anatomical positions of carcasses (lateral, ventral and dorsal-up).
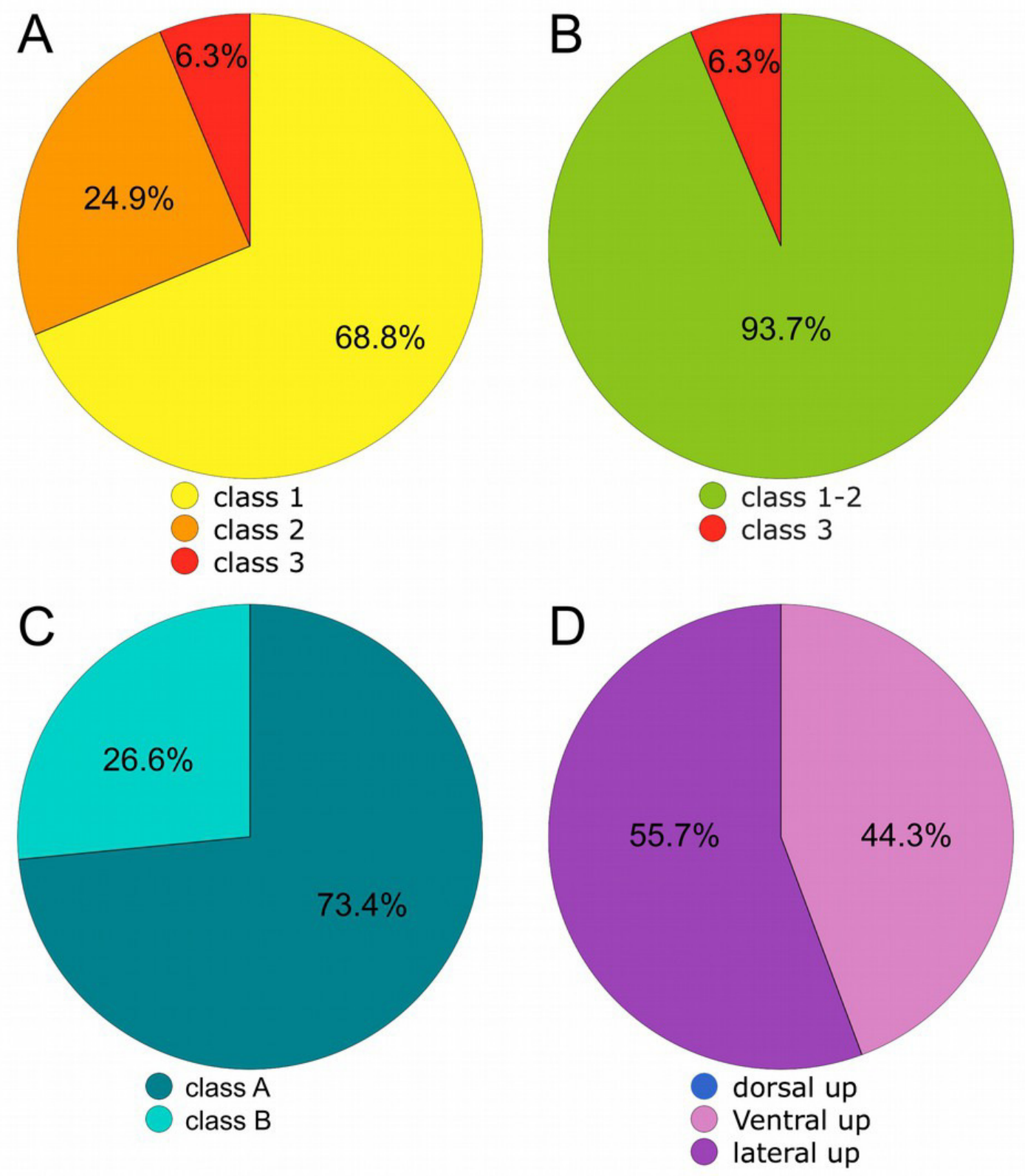
839 Fig. 12: Location of beached carcasses (blue) predicted by the drift model from four possible

840 mortality locations (red stars). Mortalities during a 2-month period are simulated, from mid

841 February to mid April 2015, with multiple carcasses $(n=200)$ of varying drift properties released

842 each day to predict the range of resulting carcass locations. Green vectors show time-averaged

843 surface currents for this period (HYCOM model). Depth contours at $50 \mathrm{~m}$ and $100 \mathrm{~m}$ are

844 indicated (GEBCO), although nearshore waters and inlets are not resolved.
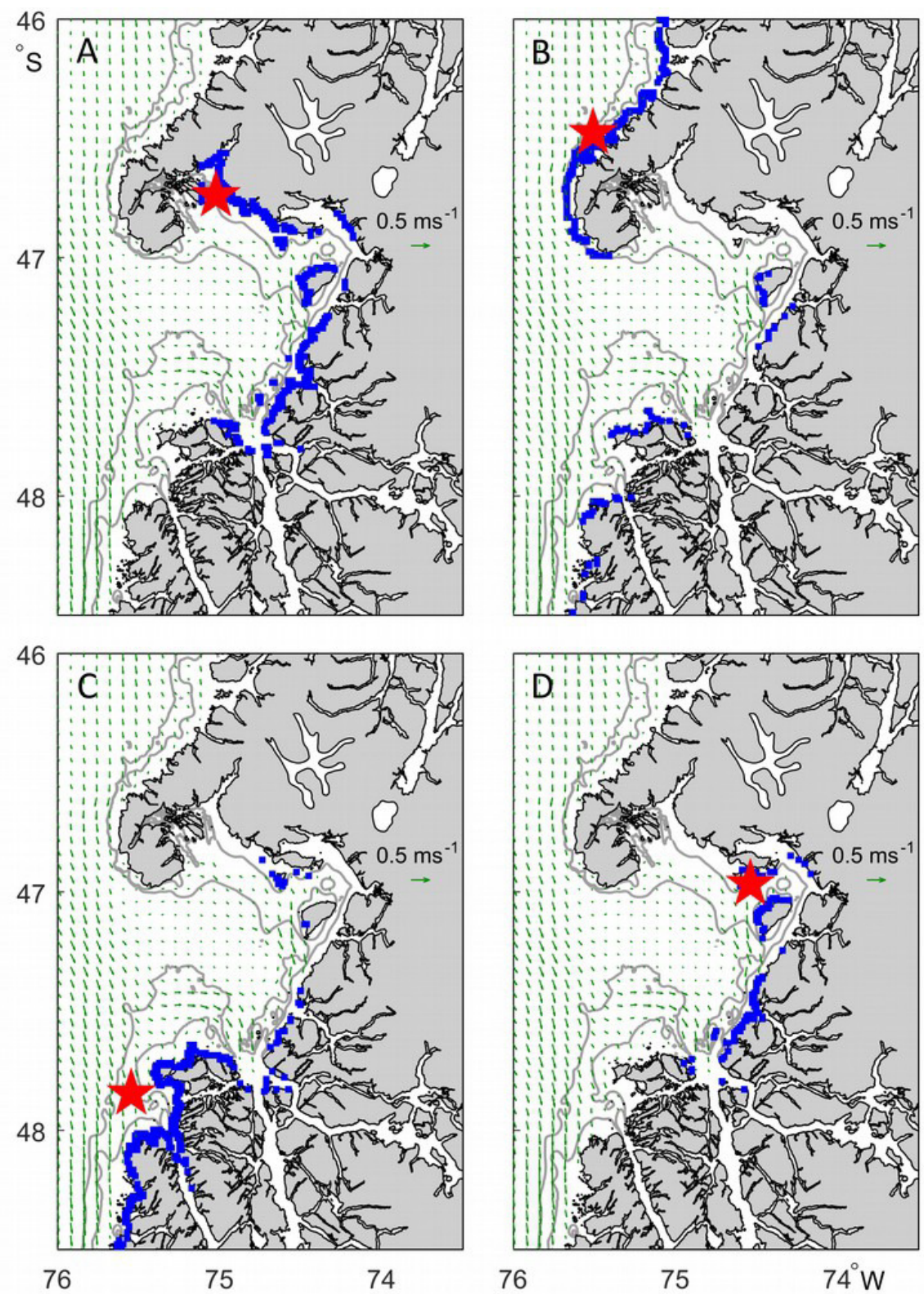
845 Fig. 13: Cumulative alongshore component of near-shore wind stress (red) from ECMWF ERA846 Interim reanalysis winds at three latitudes, with an origin time of the vernal equinox, September 84721,2014 . Gray shading shows the envelope of variability experienced during 1995-2014, with 848 darker shading indicating one standard deviation from the mean for this period. Vertical lines 849 show the timing of vessel (green) and aerial (blue) observations of whale carcasses.
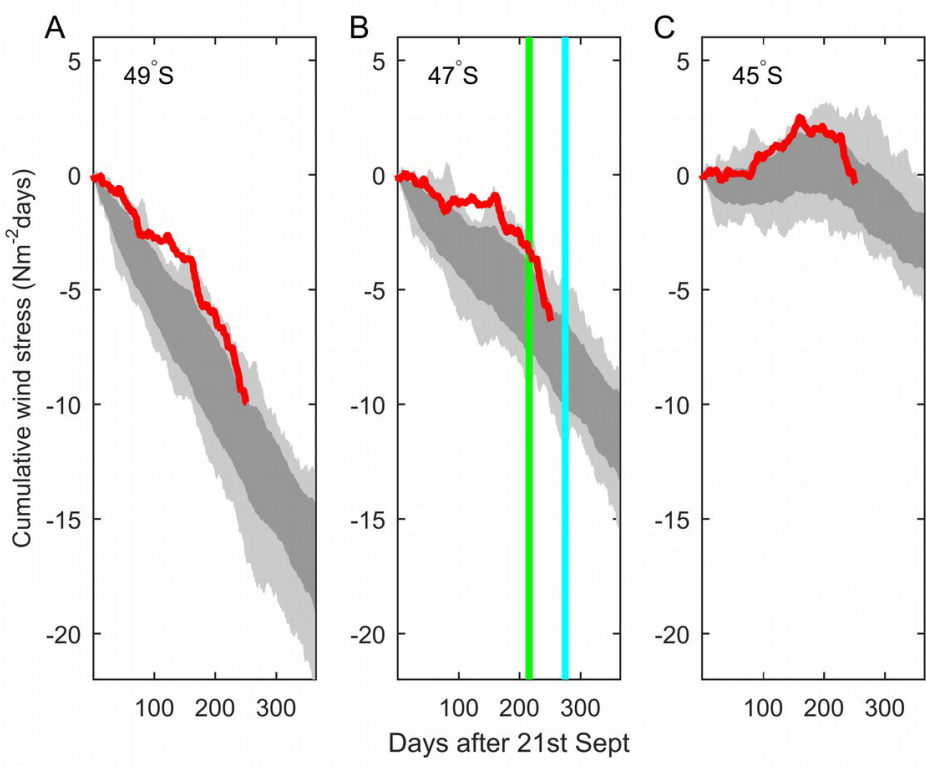
850 Fig. 14: Spatial distribution of PST (STX. Eq./100g tissue) as measured in mytilids and the 851 relative abundance of Alexandrium catenella between $43^{\circ} \mathrm{S}$ and $51^{\circ} \mathrm{S}$ in March 2015 . Insert 852 shows the toxin level at the closest site to the Golfo de Penas, Isla Canquenes $\left(45^{\circ} 43^{\prime} 31^{\prime \prime} \mathrm{S} ; 7^{\circ} 06\right.$ 853 '51"W) measured between March 2010 and March 2015. Shellfish consumption is unsafe for 854 humans if values rise above $80 \mu \mathrm{g}$ STX. Eq./100g tissue.

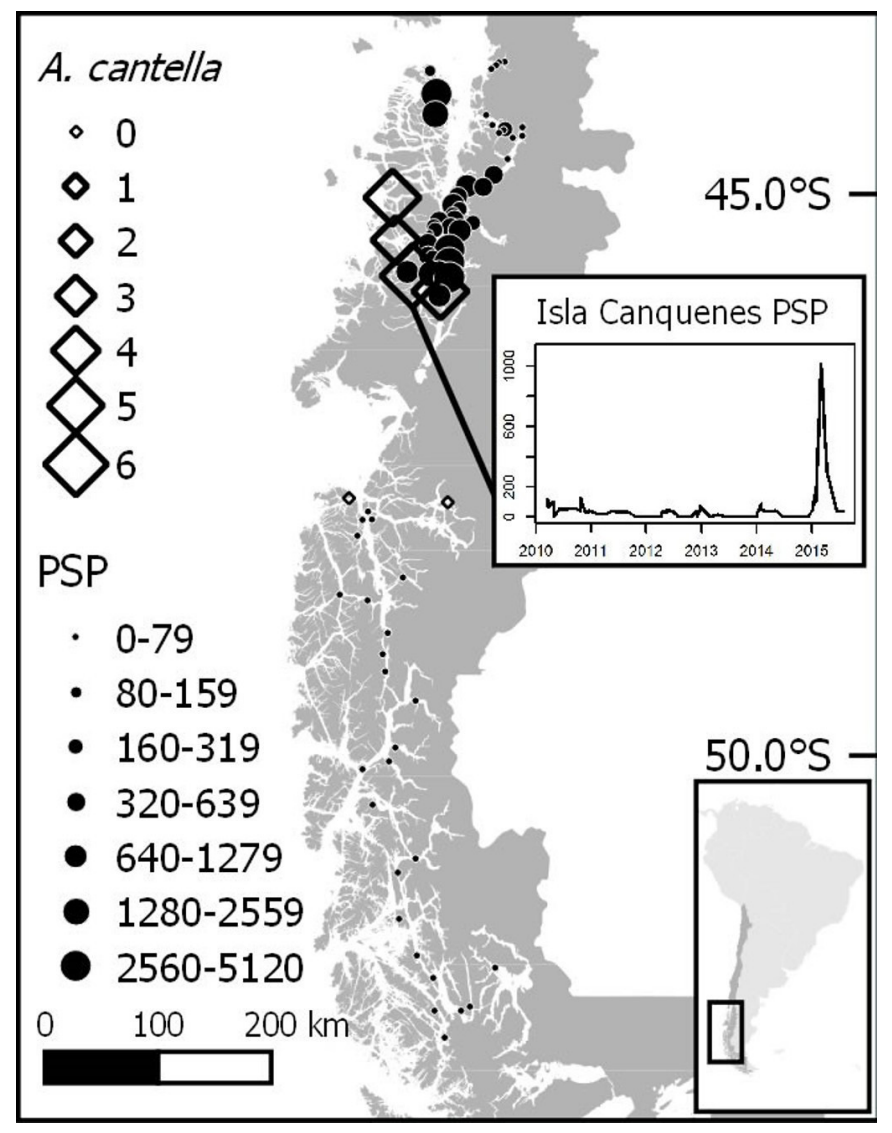


855 Fig. 15: Spatial distribution of PST (STX. Eq./100g tissue) as measured in mytilids between $43^{\circ} \mathrm{S}$

856 and $51^{\circ} \mathrm{S}$ in March 2016. In 2016, the PST levels in the Golfo Tres Montes region were not

857 elevated. However, values four to seven times higher than usual peaks were measured in the

858 channels of Central Patagonia. Shellfish consumption is unsafe for humans if values rise above

$85980 \mu \mathrm{g}$ STX. Eq./100g tissue.

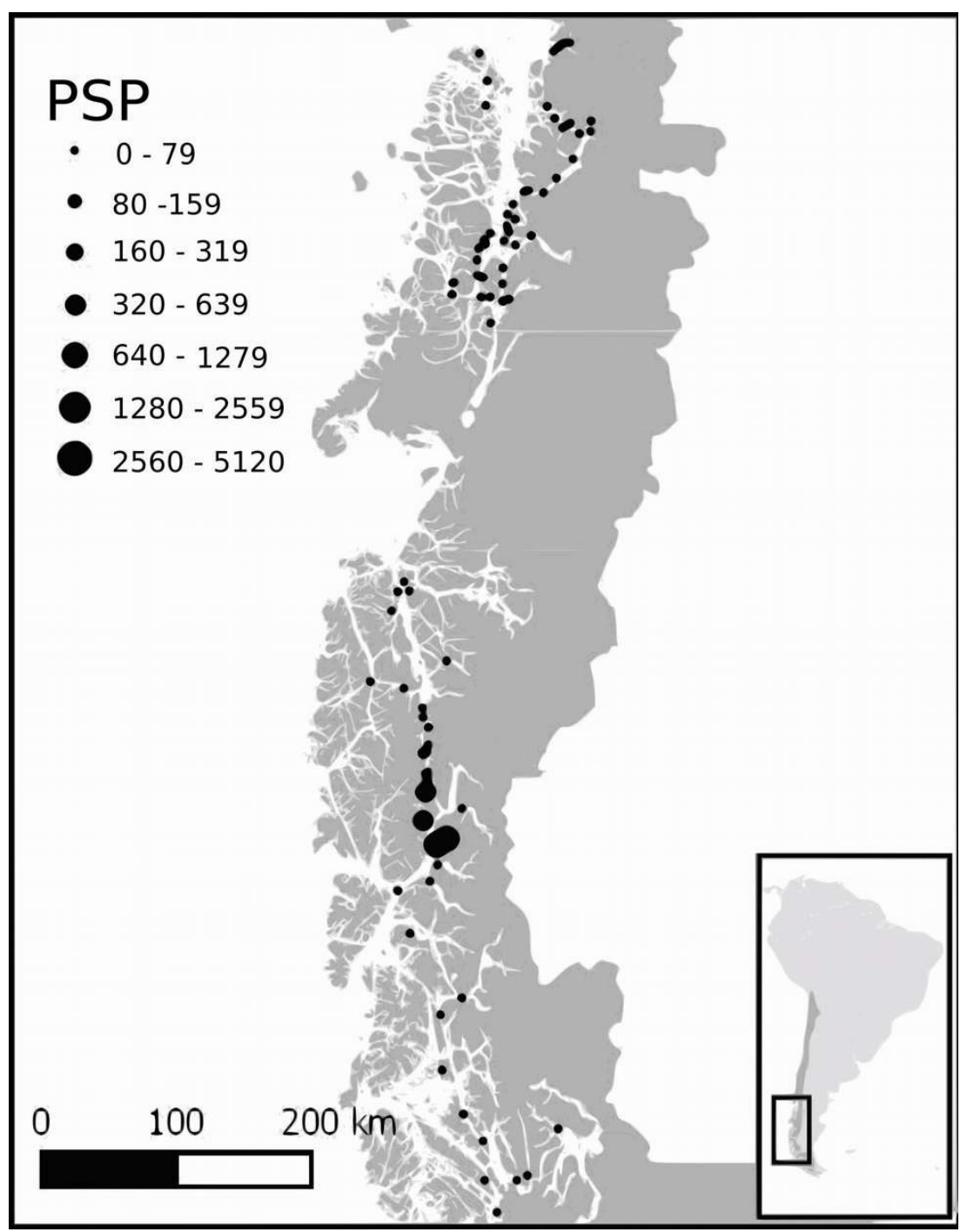


860 Fig. 16: Wind roses at the entrance to two inlets, Seno Newman (A) and Estero Slight (B), 861 derived from a local high-resolution implementation of the WRF model. Spoke lengths indicate 862 the frequency of occurrence of winds from each direction. Colors represent speed. Seno Newman 863 has a significant up-inlet component (winds from SSW) but Estero Slight does not (winds from 864 NNE).

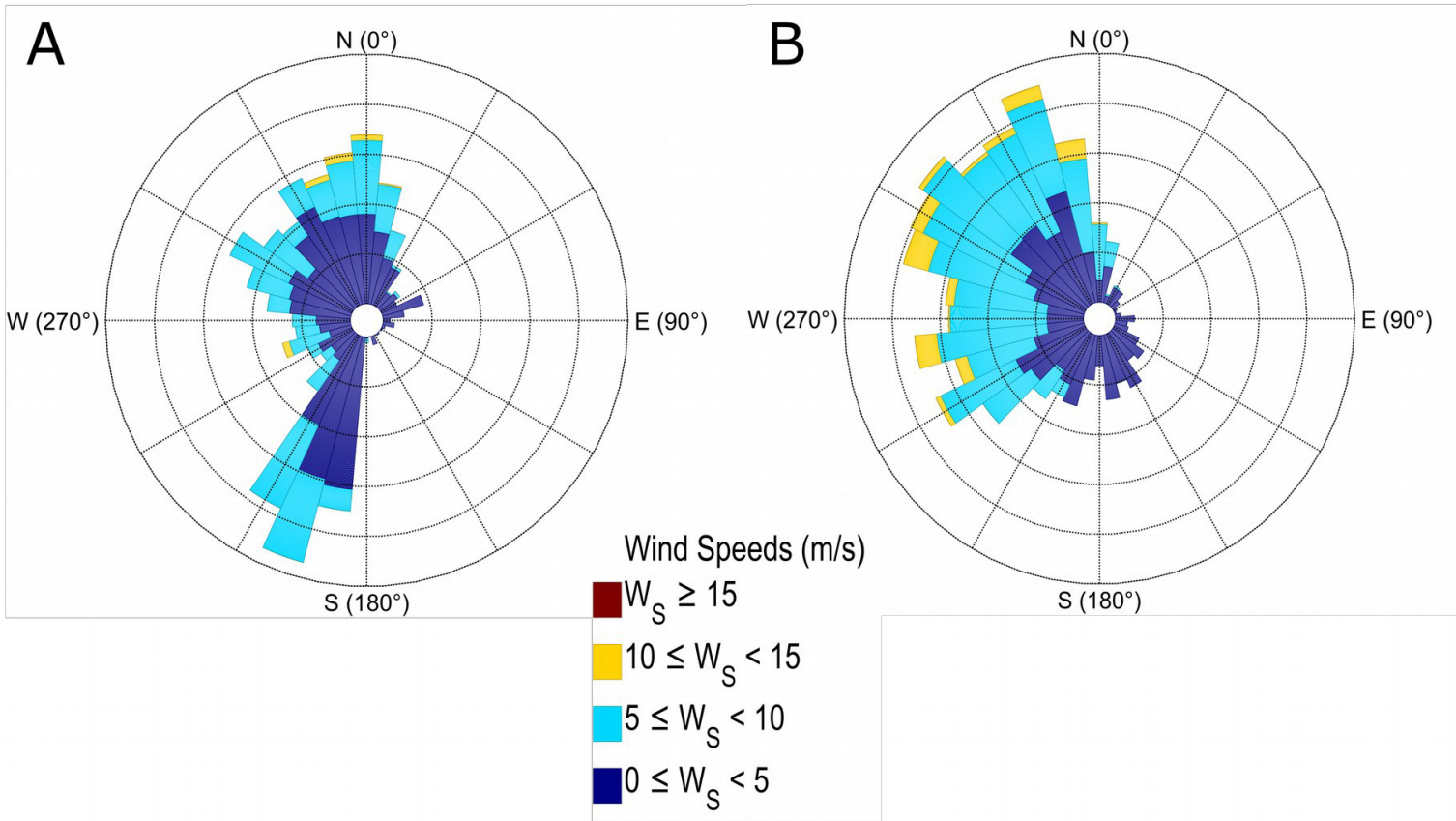


Fig. 17: Nautical maps of Escondido and Slight Inlet. A) Section of the Bahia San Quintin showing Escondido Inlet (maximum depth 15m). B) Section of Hoppner Bay showing Estero

868 Inlet is poorly charted with only five depths indicated along the inlet, the largest being $82 \mathrm{~m}$.

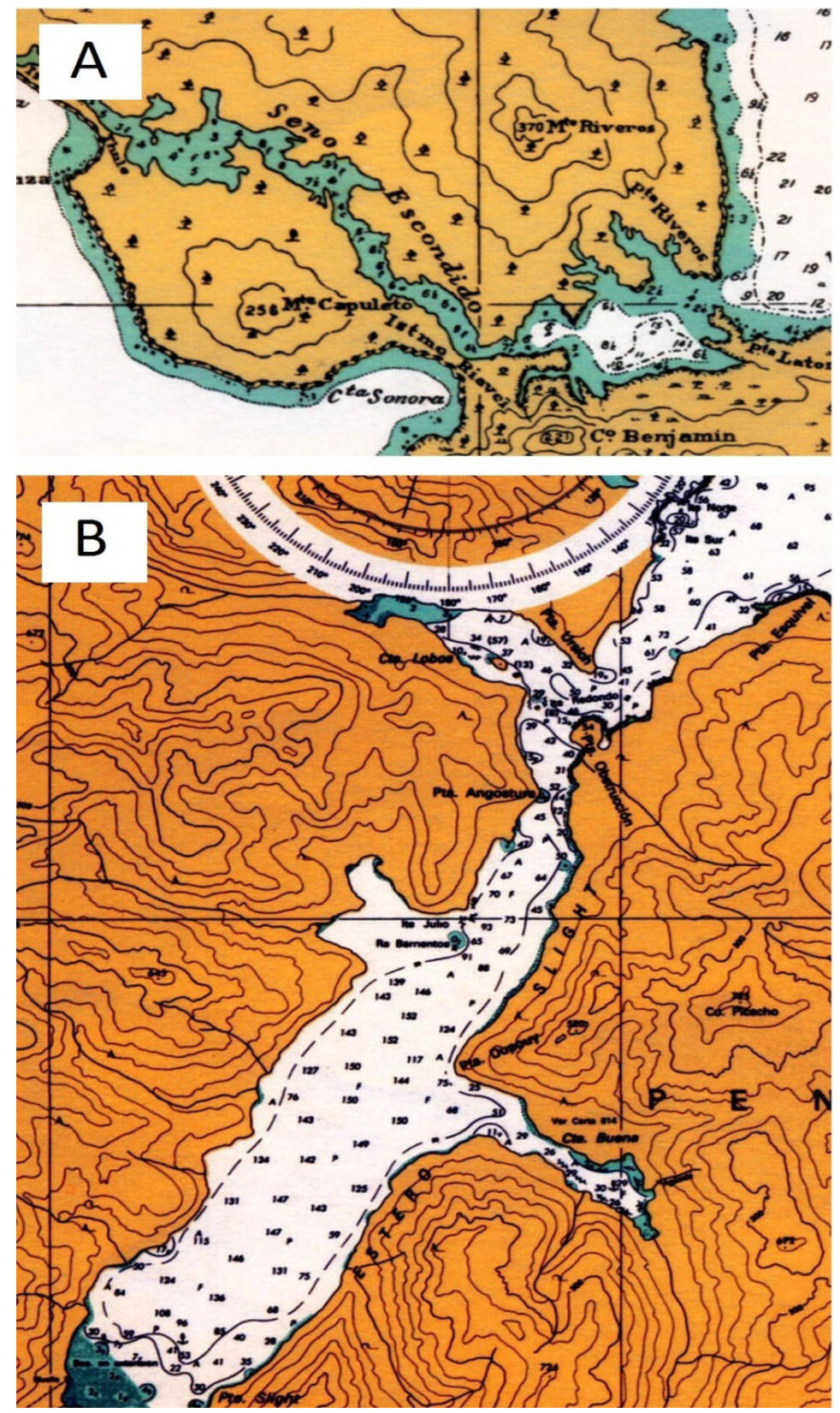


869 Table 1: Recorded mass mortality events of baleen whales (updated from Table 1 in Rowntree et 870 al. (2013))

\section{Region/site Time span Species Number Age classes Cause of death Source}

\begin{tabular}{lcccc}
\hline Caleta Buena/Slight November/Decembe & rorqual & $\begin{array}{c}4 \text { fresh, } \\
\text { numerous } \\
\text { Inlet, Southern Chile }\end{array}$ r 1977 & unknown & Pers. Comm. Salas \\
M, 2015
\end{tabular}

\begin{tabular}{llllll}
\hline Cape Cod (USA) & 5 weeks (11/1987) & humpback & 14 & HAB (saxitoxin) & Geraci et al., 1989
\end{tabular}

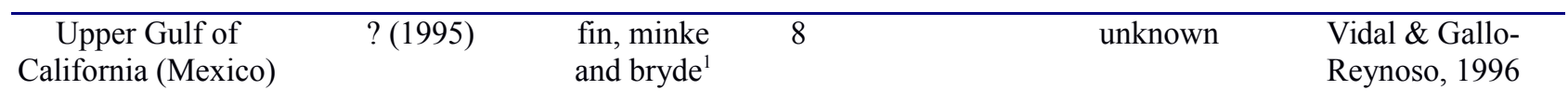

\begin{tabular}{lllllll}
\hline $\begin{array}{c}\text { Eastern North East } \\
\text { Pacific }\end{array}$ & throughout 1999 & gray & $283^{2}$ & $\begin{array}{c}\text { mostly } \\
\text { adults }\end{array}$ & malnutrition? & Gulland et al., 2005 \\
\hline $\begin{array}{c}\text { Eastern North East } \\
\text { Pacific }\end{array}$ & throughout 2000 & gray & 368 & $\begin{array}{c}\text { mostly } \\
\text { adults }\end{array}$ & malnutrition? & Gulland et al., 2005 \\
& & & & &
\end{tabular}

\begin{tabular}{cccccc}
\hline Upper Gulf of & $?(2009)$ & unknown & 10 & unknown & Rowntree et al., 2013 \\
California (Mexico) & & & & &
\end{tabular}

\begin{tabular}{ccccccc}
\hline Australia & throughout 2009 & humpback & 46 & $\begin{array}{c}\text { mostly } \\
\text { calves and } \\
\text { juv. }\end{array}$ & unknown & Coughran et al., 2013 \\
\hline Brazil & throughout 2010 & humpback & 96 & $\begin{array}{c}\text { mostly } \\
\text { calves and } \\
\text { juv. }\end{array}$ & unknown & Rowntree et al., 2013 \\
\hline $\begin{array}{c}\text { Peninsula Valdés } \\
\text { (Argentina) }\end{array}$ & $2005-2011^{3}$ & $\begin{array}{c}\text { southern } \\
\text { right }\end{array}$ & 420 & $\begin{array}{c}\text { mostly } \\
\text { calves }\end{array}$ & $\begin{array}{c}\text { unknown (HAB- } \\
\text { related?, } \\
\text { starvation?, kelp } \\
\text { gull harassment?) }\end{array}$ & 2015; Wilson, 2015 \\
\hline
\end{tabular}

\begin{tabular}{llclcc}
\hline $\begin{array}{c}\text { Puerto Edén area } \\
\text { (Chile) }\end{array}$ & March 2011 & $\begin{array}{c}\text { sei and/or } \\
\text { minke }\end{array}$ & 3 & unknown & this paper \\
\hline Estero Cono (Chile) & March 2012 & $\begin{array}{c}\text { sei and/or } \\
\text { minke }\end{array}$ & 15 & unknown & $\begin{array}{c}\text { Pers. comm. Fischer } \\
\text { RM, 2015 }\end{array}$ \\
\hline
\end{tabular}

\begin{tabular}{|c|c|c|c|c|c|}
\hline $\begin{array}{l}\text { Puerto Edén area } \\
\text { (Chile) }\end{array}$ & January 2014 & $\begin{array}{l}\text { sei and/or } \\
\text { minke }\end{array}$ & 5 & unknown & $\begin{array}{l}\text { Pers. comm. Cristie } \\
\text { C, } 2015\end{array}$ \\
\hline
\end{tabular}

\begin{tabular}{ccccccc}
\hline $\begin{array}{c}\text { Between } 46^{\circ} \text { and } \\
51^{\circ} \mathrm{S} \text {, mainly Golfo } \\
\text { de Penas (Chile) }\end{array}$ & $\begin{array}{c}\text { February to early } \\
\text { April } 2015^{4}\end{array}$ & $\begin{array}{c}\text { probably all } \\
\text { sei }\end{array}$ & 305 & all & HAB & this paper \\
\hline $\begin{array}{c}\text { Alaska/British } \\
\text { Columbia }\end{array}$ & Mai/June 2015 & $\begin{array}{c}\text { fin, } \\
\text { humpback, } \\
\text { grey }\end{array}$ & 38 & unknown (HAB?) & NOAA, 2015b \\
\hline
\end{tabular}

$871{ }^{1}$ In total, 400 cetaceans died, including 8 baleen whales

$872 \quad{ }^{2} 106$ in Mexico during 3 months

$873 \quad{ }^{3} 116$ died during 2012

$874 \quad{ }^{4} 271$ died within one month

\section{Table 2 (separate file)}


876 Table 3 - Proportion of carcasses in each anatomical position as recorded from the overflight

877 survey and posterior photographic analysis.

\begin{tabular}{cccccc} 
Anatomical position of Carcass & Unkown & Dorsal Up & Ventral Up & Lateral Up & Total \\
\hline Count & 187 & 0 & 43 & 54 & $\mathbf{9 7}$ \\
$\begin{array}{c}\text { Proportion (\%) } \\
\text { Proportion (\%) based on classified } \\
\text { individuals only }\end{array}$ & - & 0 & $15.14 \%$ & $19.01 \%$ & $\mathbf{1 0 0}$ \\
& & 0 & $44 \%$ & $56 \%$ & $\mathbf{1 0 0}$
\end{tabular}


878 Table 4 - Minimal number of individuals (MNI) and proportion of carcasses in each of the 879 classes of decomposition / disarticulation stages recorded at Golfo de Penas.

\begin{tabular}{cccc} 
& Class & MNI & Proportion (\%) \\
\hline Classes of decomposition & & & \\
\hline Time since death & 1 & 141 & 68.78 \\
& 2 & 51 & 24.88 \\
& 3 & 13 & 6.34 \\
& Total & $\mathbf{2 0 5}$ & $\mathbf{1 0 0}$ \\
\hline Time at sea & A & 147 & 97.35 \\
& B & 4 & 2.64 \\
& Total & $\mathbf{1 5 1}$ & $\mathbf{1 0 0}$
\end{tabular}

880 Table 5. Density of specimens in assemblages (specimens $/ \mathrm{km}^{2}$ ).

\begin{tabular}{lccc} 
& $\begin{array}{c}\text { Area } \\
\mathbf{( k m}^{\mathbf{2}}\end{array}$ & No. of specimens & $\begin{array}{c}\text { Density } \\
\text { (specimens/(km } \mathbf{~})\end{array}$ \\
\hline Assemblage 1 - Jungfrauen Group & 0.19 & 30 & 156 \\
Assemblage 2 - Escondido Inlet & 0.02 & 47 & 1906 \\
Assemblage 3 - Escondido Inlet & 0.01 & 32 & 1987 \\
Assemblage 4 - Newman Inlet & 0.60 & 149 & 248 \\
Assemblage 5 - Slight Inlet & 0.04 & 40 & 952 \\
Total area of assemblages/specimens & 0.87 & 298 & 341 \\
Average & 0.17 & 59 & 1050
\end{tabular}


Penas.

\begin{tabular}{|c|c|c|c|c|c|c|c|c|}
\hline $\begin{array}{l}\text { Cause of death } \\
\text { for marine } \\
\text { mammals }\end{array}$ & Main feature & $\begin{array}{c}\text { Type of } \\
\text { evidence } \\
\text { (confirm- } \\
\text { discard) }\end{array}$ & $\begin{array}{l}\text { Observation at } \\
\text { Golfo de Penas }\end{array}$ & $\begin{array}{l}\text { Expected in } \\
\text { rorqual event }\end{array}$ & $\begin{array}{l}\text { Oceanographic } \\
\text { conditions near } \\
\text { time of death }\end{array}$ & $\begin{array}{l}\text { Rorqual Species } \\
\text { recorded }\end{array}$ & References & $\begin{array}{c}\text { Oceanographic } \\
\text { Conditions } \\
\text { Observed at GP }\end{array}$ \\
\hline $\begin{array}{l}\text { Starvation by } \\
\text { abundance } \\
\text { surpassing } \\
\text { carrying } \\
\text { capacity }\end{array}$ & $\begin{array}{l}\text { Thin blubber } \\
\text { layer, or } \\
\text { empty } \\
\text { stomach, or } \\
\text { numbers } \\
\text { around } 5 \% \text { of } \\
\text { population }\end{array}$ & $\begin{array}{l}\text { Measurement } \\
\text { s, necropsy } \\
\text { and } \\
\text { population } \\
\text { numbers } \\
\text { nearby } \\
\text { carrying } \\
\text { capacity }\end{array}$ & $\begin{array}{l}\text { Not likely, Sei } \\
\text { whales are still } \\
\text { recovering from } \\
\text { whaling, last } \\
\text { species to be } \\
\text { hunted }\end{array}$ & $\begin{array}{l}\text { Reported in } \\
\text { one species }\end{array}$ & $\begin{array}{c}\text { Low } \\
\text { productivity } \\
\text { event }\end{array}$ & $\begin{array}{l}\text { Unknown. } \\
\text { Reported in } \\
\text { gray whales } \\
\text { (Eschrichthius } \\
\text { robustus). }\end{array}$ & $\begin{array}{l}\text { Gulland et al. } \\
2005\end{array}$ & $\begin{array}{c}\text { High } \\
\text { productivity } \\
\text { event }\end{array}$ \\
\hline $\begin{array}{l}\text { Epidemic } \\
\text { Disease }\end{array}$ & $\begin{array}{l}\text { Morbillivirus } \\
\text { : Contagious- } \\
\text { epidemic, } \\
\text { emaciated, } \\
\text { external and } \\
\text { internal } \\
\text { parasites, } \\
\text { lesions and } \\
\text { inflammatory } \\
\text { reactions }\end{array}$ & $\begin{array}{l}\text { Histology, } \\
\text { parasitology- } \\
\text { virology test }\end{array}$ & $\begin{array}{c}\text { No signs of } \\
\text { external or } \\
\text { internal lesions } \\
\text { in the whales of } \\
\text { Estero Slight. } \\
\text { Stomach } \\
\text { content present. } \\
\text { No test } \\
\text { available. }\end{array}$ & $\begin{array}{c}\text { Low numbers, } \\
\text { young } \\
\text { individuals. }\end{array}$ & $\begin{array}{c}\text { Shift in } \\
\text { temperature, } \\
\text { anthropogenic } \\
\text { contamination, } \\
\text { mutation of } \\
\text { virus. }\end{array}$ & $\begin{array}{l}\text { Juveniles and } \\
\text { calves fin } \\
\text { whales, } \\
\text { Balaenoptera } \\
\text { physalus }\end{array}$ & $\begin{array}{c}\text { Brongersma- } \\
\text { Sanders 1957, } \\
\text { Jauniaux et al. } \\
\text { 2000, Shimizu } \\
\text { et al 2013, Van } \\
\text { Bressem et al. } \\
\text { 2014, } \\
\text { Mazzariol et } \\
\text { al. } 2016\end{array}$ & Unknown \\
\hline $\begin{array}{l}\text { Military } \\
\text { exercise with } \\
\text { Sonar }\end{array}$ & $\begin{array}{l}\text { Only } \\
\text { confirmed in } \\
\text { dolphins }\end{array}$ & $\begin{array}{l}\text { ear damage } \\
\text { and - or } \\
\text { haemorrhage } \\
\text { nearby the } \\
\text { ears }\end{array}$ & Unknown & Unknown & $\begin{array}{l}\text { No military } \\
\text { exercises public } \\
\text { programed, } \\
\text { chilean law for } \\
\text { the protection } \\
\text { of whales }\end{array}$ & Unknown & $\begin{array}{l}\text { Goldbogen et } \\
\text { al. } 2013 \text {, } \\
\text { Nowacek et al. } \\
2007 \text {, Southall } \\
\text { et al. } 2007\end{array}$ & Not reported \\
\hline $\begin{array}{l}\text { Poisoning by } \\
\text { toxins of } \\
\text { Harmful Algal } \\
\text { Bloom }\end{array}$ & $\begin{array}{l}\text { Massive, } \\
\text { multispecific, } \\
\text { recurrent in } \\
\text { time }\end{array}$ & $\begin{array}{c}\text { HAB } \\
\text { reported, } \\
\text { shift in } \\
\text { oceanographi } \\
\text { c conditions, } \\
\text { El Niño } \\
\text { event }\end{array}$ & i & Yes & $\begin{array}{l}\text { High } \\
\text { productivity } \\
\text { event, El Niño } \\
\text { influence }\end{array}$ & $\begin{array}{l}\text { Balaenoptera } \\
\text { physalus, } \\
\text { Megaptera } \\
\text { novaeangliae, } \\
\text { Balaenoptera } \\
\text { acutorostrata }\end{array}$ & $\begin{array}{l}\text { Geraci et al. } \\
\text { 1989, Fire et } \\
\text { al. 2010, } \\
\text { Pyenson et al. } \\
\text { 2014, } \\
\text { Brongersma- } \\
\text { Sanders 1957. } \\
\text { (Present work) }\end{array}$ & $\begin{array}{l}\text { Yes, at the } \\
\text { closest station } \\
\text { of red tide } \\
\text { monitoring. }\end{array}$ \\
\hline $\begin{array}{l}\text { Trauma: Ship } \\
\text { collision/ } \\
\text { entanglement }\end{array}$ & $\begin{array}{c}\text { Evidence of } \\
\text { trauma, small } \\
\text { number (i.e. } \\
8 \text { deaths in } \\
19 \text { years in } \\
\text { U.S.A.) }\end{array}$ & $\begin{array}{c}\text { Lesions, } \\
\text { hematoma, }\end{array}$ & $\begin{array}{c}\text { No sign of } \\
\text { internal or } \\
\text { external lesion. }\end{array}$ & $\begin{array}{l}\text { Yes (small } \\
\text { number of } \\
\text { individuals at } \\
\text { a time) }\end{array}$ & Not related. & $\begin{array}{l}\text { Eubalaena } \\
\text { glacialis }\end{array}$ & $\begin{array}{c}\text { Kraus, 1990; } \\
\text { Moore et al. } \\
2004, \\
\text { Vanderlann y } \\
\text { Taggart, } 2007 .\end{array}$ & Not related. \\
\hline
\end{tabular}


883 Table 7 - Main biostratinomic pathways and their significance in understanding the 884 thanatocenosis.

\begin{tabular}{|c|c|c|c|c|c|}
\hline $\begin{array}{l}\text { Time since } \\
\text { death }\end{array}$ & $\begin{array}{l}\text { Condition of the } \\
\text { carcasses }\end{array}$ & Age proportions & Sex proportions & $\begin{array}{l}\text { Geographic } \\
\text { position }\end{array}$ & Observed \\
\hline $\begin{array}{l}\text { Catastrophic - } \\
\text { single event }\end{array}$ & $\begin{array}{l}\text { Highly } \\
\text { homogenous. } \\
\text { Majority within } \\
\text { one to a few } \\
\text { classes (42) }\end{array}$ & $\begin{array}{l}\text { Same as } \\
\text { population rate }\end{array}$ & $\begin{array}{l}\text { Same as population } \\
\text { rate }\end{array}$ & Homogenous & $\begin{array}{l}\text { Homogenous; } \\
\text { see Tab. S2 }\end{array}$ \\
\hline Time averaged & $\begin{array}{l}\text { Highly } \\
\text { heterogeneous. } \\
\text { Several classes } \\
\text { present. }\end{array}$ & $\begin{array}{l}\text { Same as } \\
\text { proportion of } \\
\text { annual mortality } \\
\text { of the } \\
\text { population. }\end{array}$ & $\begin{array}{l}\text { No pattern, different } \\
\text { from ratio of } \\
\text { population. }\end{array}$ & Heterogeneous & $\begin{array}{l}\text { Homogenous; } \\
\text { see Tab. S2 }\end{array}$ \\
\hline $\begin{array}{l}\text { Location of } \\
\text { death }\end{array}$ & $\begin{array}{l}\text { Condition of the } \\
\text { carcasses }\end{array}$ & $\begin{array}{l}\text { Anatomic } \\
\text { position } \\
\text { expected }\end{array}$ & $\begin{array}{l}\text { Anatomic position } \\
\text { expected }\end{array}$ & Orientation & $\begin{array}{l}\text { Anatomic } \\
\text { position } \\
\text { observed }\end{array}$ \\
\hline Authoctonous & $\begin{array}{l}\text { Very well } \\
\text { preserved, low } \\
\text { disarticulation }\end{array}$ & $\begin{array}{l}\text { Position of life: } \\
\text { dorsal up (5). }\end{array}$ & Dorsal up & No trend & $\begin{array}{l}\text { Dorsal up: } \\
1.00 \%\end{array}$ \\
\hline Allocthonous & $\begin{array}{l}\text { Disarticulation } \\
\text { and scattering } \\
\text { present, depending } \\
\text { on time and } \\
\text { distance to final } \\
\text { deposit }\end{array}$ & $\begin{array}{l}\text { Heterogeneous } \\
\text { depending on } \\
\text { time since death } \\
\text { or time of drift. } \\
\text { Majority ventral } \\
\text { to lateral up (5, } \\
\text { see Fig. S5). }\end{array}$ & $\begin{array}{l}\text { Ventral up - } \\
\text { lateral up }\end{array}$ & $\begin{array}{l}\text { One main } \\
\text { direction } \\
\text { (current-wind) } \\
\text { and/or two main } \\
\text { directions (tide) }\end{array}$ & $\begin{array}{l}\text { Ventral up: } \\
20.40 \% \\
\text { Lateral Up: } \\
78.61 \%\end{array}$ \\
\hline
\end{tabular}


885 Table 8 - Sei whales observed in Chilean Patagonia (whaling ended in 1976).

\begin{tabular}{|c|c|c|c|c|}
\hline Region/site & No. of whales & Time span & Distance to shore (mi) & Source \\
\hline $43-45^{\circ} \mathrm{S}$ & 286 & 25 March - 03 Apr. 1966 & $60-70$ & Aguayo-Lobo 1974 \\
\hline $39-41^{\circ} \mathrm{S}$ & 345 & 09-20 Oct. 1966 & $60-120$ & Aguayo-Lobo 1974 \\
\hline $46-48^{\circ} \mathrm{S}$ & 114 & 13-23 Dec. 1966 & $20-60$ & Aguayo-Lobo 1974 \\
\hline $\begin{array}{l}\text { Penas Gulf } \\
\left(\sim 46^{\circ} 30^{\prime}-48^{\circ} \mathrm{S}\right)\end{array}$ & 600 & March 1966 & $11-24$ & $\begin{array}{l}\text { Pastene, L. pers. } \\
\text { comm., } 2015\end{array}$ \\
\hline $\begin{array}{l}\text { Penas Gulf } \\
\left(\sim 46^{\circ} 30^{\prime}-48^{\circ} \mathrm{S}\right)\end{array}$ & small number & 25-28 May 1971 & inshore & Gilmore, 1971 \\
\hline $53-55^{\circ} \mathrm{S}$ & $\begin{array}{c}\text { large } \\
\text { concentrations }\end{array}$ & Feb. 1994 & Not mentioned & Pastene et al., 1999 \\
\hline $\begin{array}{l}\text { Slight Inlet } \\
\left(\sim 46^{\circ} 45^{\prime} S\right)\end{array}$ & 2 & July 2015 & Near to shore & $\begin{array}{l}\text { Cabezas, J., pers. } \\
\text { comm, } 2015\end{array}$ \\
\hline
\end{tabular}

